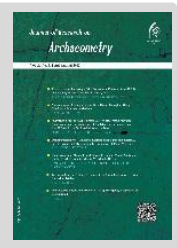

\title{
Micro-PIXE: A Powerful Technique in Measurement and Determination of Raw Materials of Glass Artifacts of Parthian period From Shaur (Susa)
}

\author{
Davoud Agha-Aligol' ${ }^{1}$, Moslem Jafarizadeh ${ }^{\star 2}$, Mahmoud Moradi $^{3}$ \\ ${ }^{1,3}$ Nuclear Science and Technology Research Institute, Physics and Accelerators Research School, Van de \\ Graaff Laboratory, Tehran, IRAN \\ ${ }^{2}$ Ph.D. in Archaeology, Tarbiat Modares University, Tehran, IRAN
}

\begin{abstract}
Investigation of scientific archaeological excavation reports in Iran indicated that these excavations yielded a large number of fragments of glass objects from many archaeological sites, but a very limited number of preliminary studies on elemental analysis of a few Iranian glass objects have been published. Also, a literature survey on pre-Islamic glass objects (especially from Parthian and Sasanian epoch) indicates that there are only a few studies on a limited number of Sasanian and Parthian glasses from Iraq, too. However, a systematic analysis of the Parthian glasses artifacts from Iran is still missing and until now, no reports has been reported about the chemical composition of Parthian glasses from Iran. Therefore, for the first time, the chemical composition of Parthian glass objects from the Shaur Palace at Susa in Khuzistan Plain have been considered. Shaur Palace locates at the west of the ancient site of Susa, next to Shaur River, Khuzestan province, south-west of Iran. It has been excavated by a joint French-Iranian team since 1970 to 1976. There were recognized three Islamic, Parthian, and Achaemenid strata. In this work, 21 glass objects date back the Parthian period were analyzed by Micro- PIXE technique in order to measure the constituent elements and to investigate the types of glass and raw materials used in the manufacturing recipe. The micro-PIXE measurement was performed with scanning proton microprobe system manufactured by Oxford Instruments using the $3 \mathrm{MV}$ Van de Graaff accelerators at the Nuclear Science \& Technology Research Institute in Atomic Energy Organization of Iran. The samples were analyzed in a vacuum chamber using a beam of $2.5 \mathrm{MeV}$ protons focused to a diameter less than $10 \mu \mathrm{m}$. The beam current was in the range of 30 to $50 \mathrm{pA}$. Characteristic X-rays were detected using a $\mathrm{Si}(\mathrm{Li})$ detector with an active area of $60 \mathrm{~mm}^{2}$ positioned at an angle of $135^{\circ}$ relative to the incident beam direction and with an energy resolution of $150 \mathrm{eV}$ for Fe-K $\alpha$. Analyzed samples were fragments of the body, rim, bottom, and handle of vessels such as bowls, bottles and beakers. They were generally green with a nacreous coating, resulted from surface corrosion due to long-term burial in the soil. Also, $90 \%$ of glass objects manufactured at Shaur Palace were manufactured on free blowing method and most of them were plain and undecorated. Elemental analysis of the glass artifacts by micro-PIXE indicated that the constituent elements of the samples are sodium, magnesium, aluminum, silicon, phosphor, sulfur, chlorine, potassium, calcium, titanium, manganese, and iron, with different concentration and weight percent percentage $(\mathrm{wt} \%)$. Determination and measurement of each of these elements respond to questions raised about the technology, type of the glass and raw materials of manufacturing recipe. The micro-PIXE analysis showed that these samples are mainely composed of $\mathrm{SiO}_{2}(63-65 \mathrm{wt} \%)$,
\end{abstract}

*Corresponding author: moslem.archaeology@gmail.com 
$\mathrm{Na}_{2} \mathrm{O}(13-18 \mathrm{wt} \%)$ and $\mathrm{CaO}$ (6-8 wt \%). Consequently, all these samples are Silica- Soda- Lime glass type. However, the amounts of magnesium oxide $(\mathrm{MgO})$ and potassium oxide $\left(\mathrm{K}_{2} \mathrm{O}\right)$ in all analyzed samples were more than $2.5 \mathrm{wt} \%$, where their contents vary between 2.5 to $5 \mathrm{wt} \%$, and 2.5 to $4.5 \mathrm{wt} \%$, respectively. Therefore, it is was clear that the ashes obtained from halophytic plants are considered as supplying source for soda in these glasses, so these glasses are Plant ash Silica- Soda- Lime type. Moreover, the micro-PIXE results clearly revealed that in the manufacturing of all shaur glass objects the same sources of silica and plant ashes have been used. In addition, the strong linear correlation of minor elements in the samples indicated that colorants and decolorizing agents have not been intentionally added in the manufacturing process.

Keywords: Glass, Shaour, Parthian, Elemental Analysis, Micro-PIXE. 


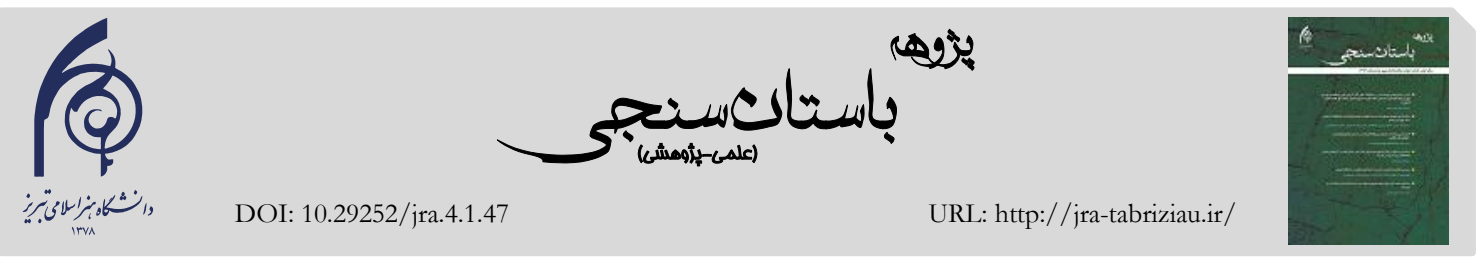

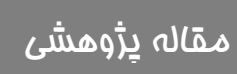

\title{
ميكروبيكسى: روشى توانمند در بر رسى و تعيين مواد

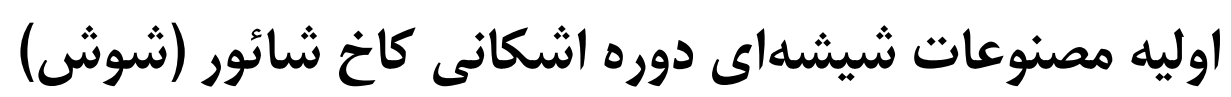

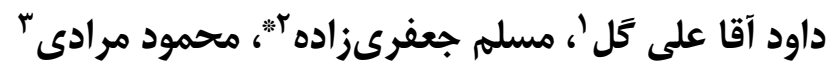

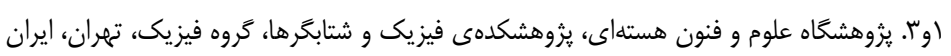

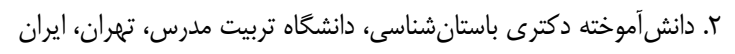

Iر تاريخ يذيرش:

Iس تاريخ دريافت:

جكيده

آَاهى از تركيب عنصرى مصنوعات شيشهاى تاريخى كاربرد بسيار زيادى در بررسى فن ساخت، تعيين مواد اوليه مورداستفاده در ساخت،

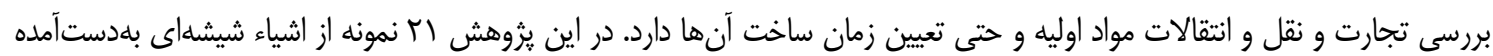

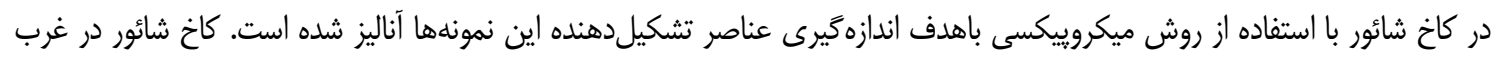

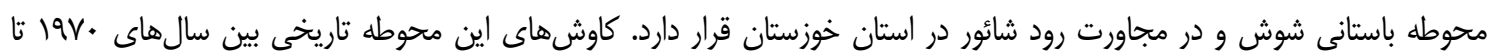

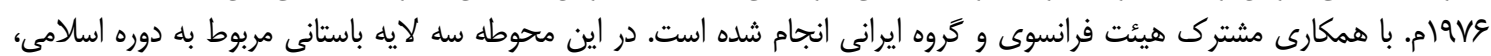

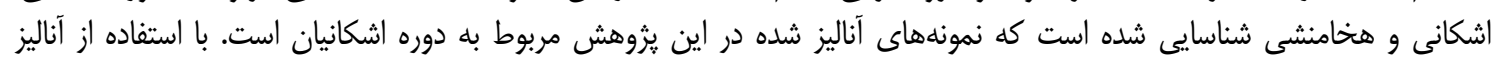

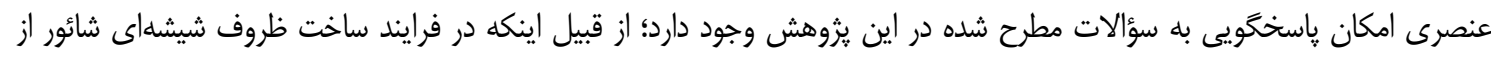

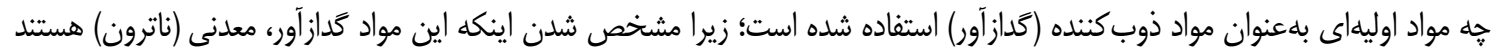

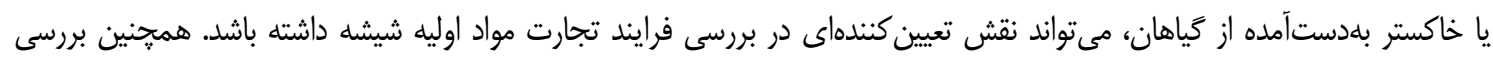

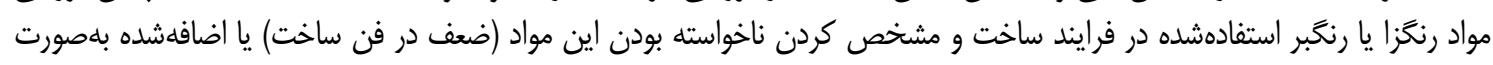

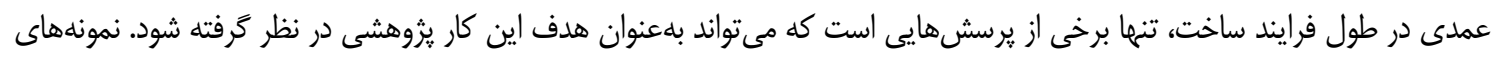

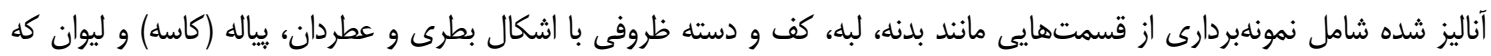

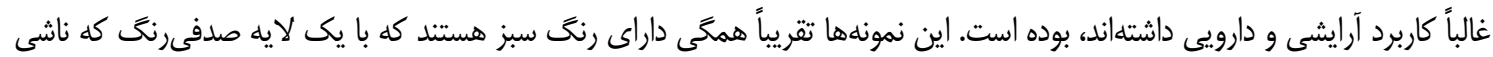

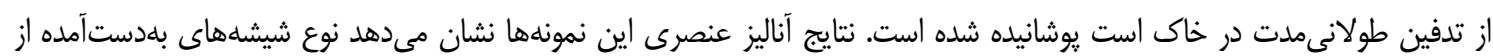

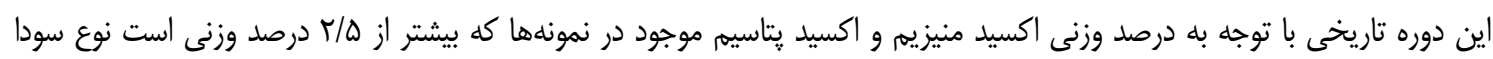

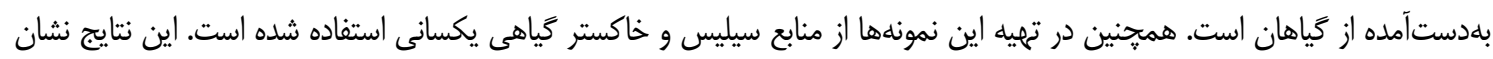

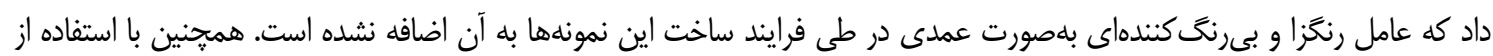

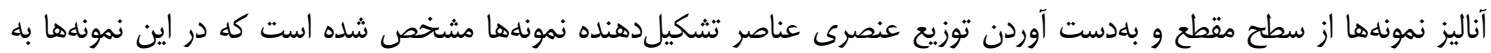

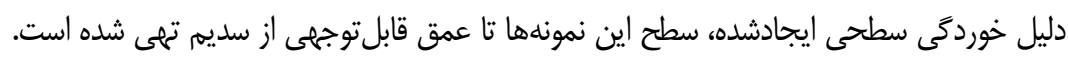
وازَّان كليدى: شيشه، شائور، اشكانى، آناليز عنصرى، ميكروييكسى.

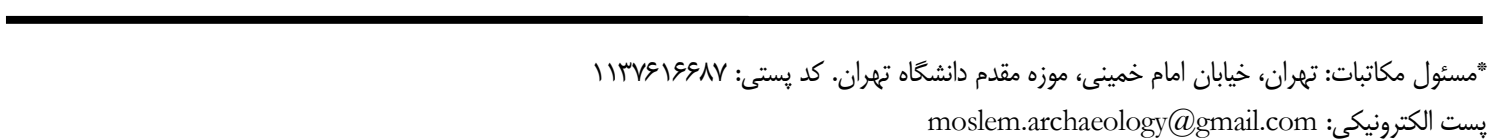

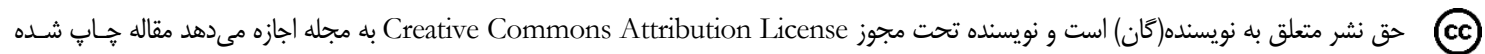
را با ديخران به اشتراك بخذارد منوط بر اينكه حقوق مؤلف اثر حفظ و به انتشار اوليه مقاله در اين مجله اشاره شود. 
هر يك از اين جهار دسته از مواد به برخى از يرسشهـاى مطرح در زمينه فنشناسى و فن ساخت، نوع شيشه و مواد

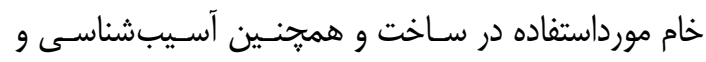

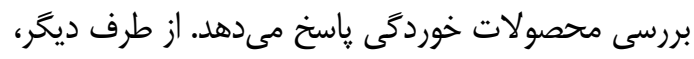

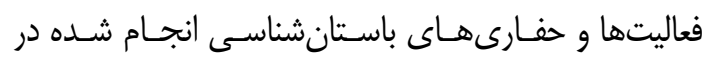

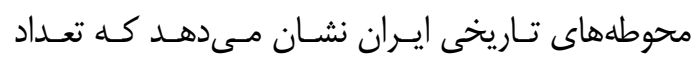

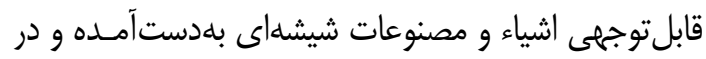

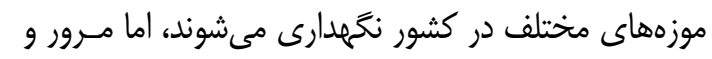

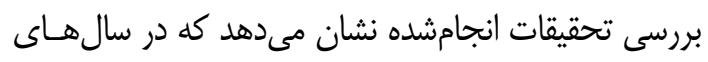
كذنشته، به صورت بسيار محدود، تنها بر روى تعداد انـدكى إنى

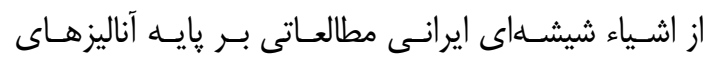
شيميايى و عنصرى انجام شده است. دشت خوزستان نيـز

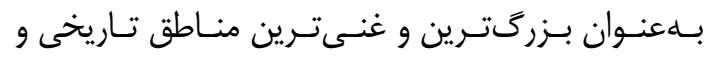

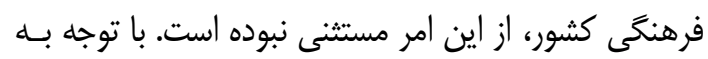

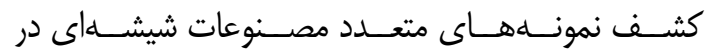
محوطههاى باستانى دشت خوزستان مثل شـوش، شـائور،

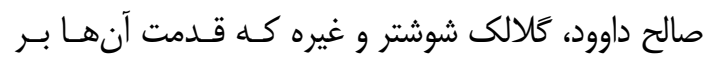

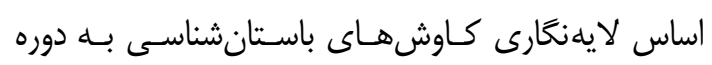

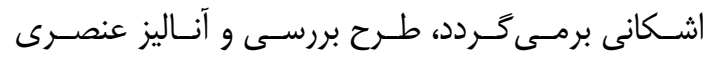

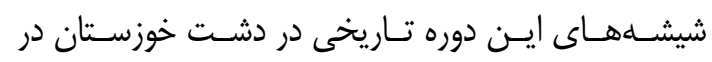

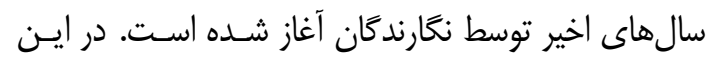

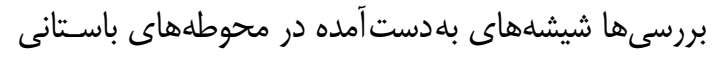

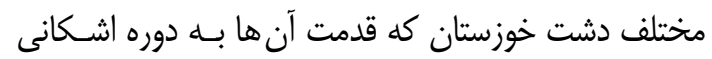

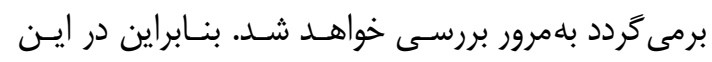

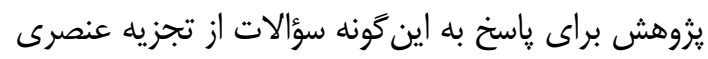

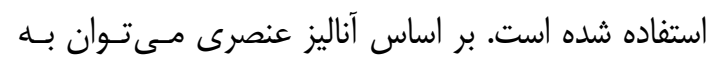

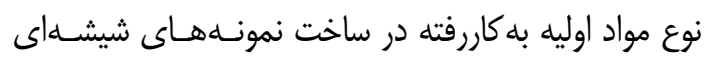

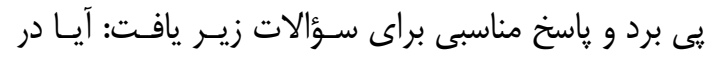

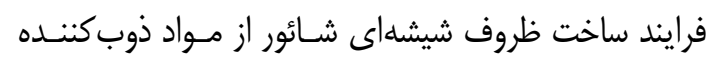

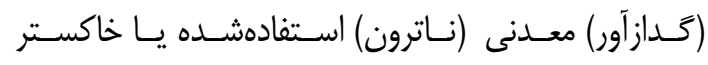

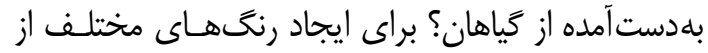

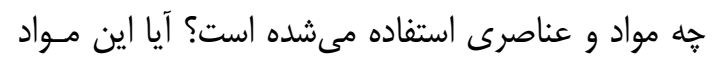
رنخزا و رنخبر بلهورت عمدى اضافه شده است يا اينكه

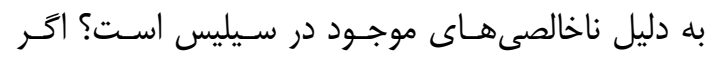

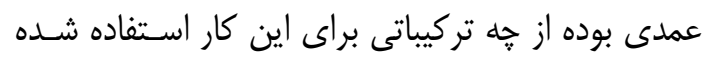

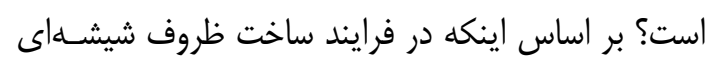

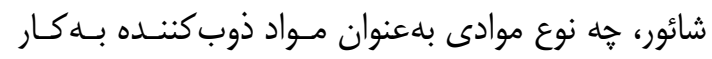

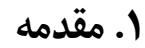
اخرجه در حال حاضر هم، جوابى قطعى به اين سـؤال كـهـ

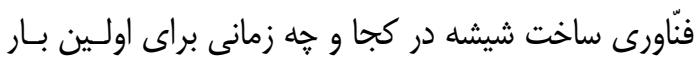

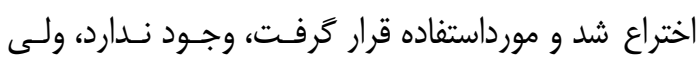

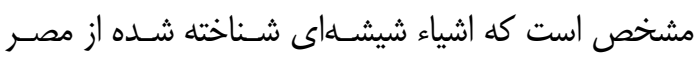

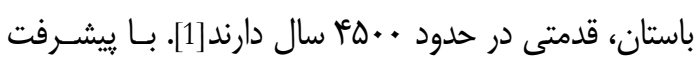

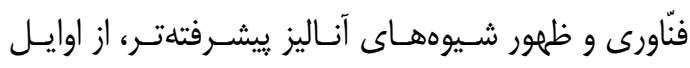

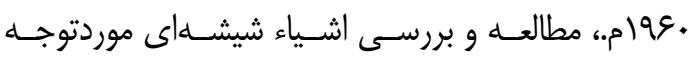

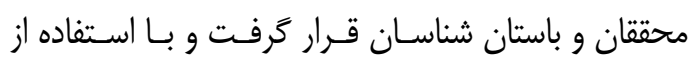
ابزارهاى علمى نوظهور به بررسى و آناليز شـيميايى تعـداد

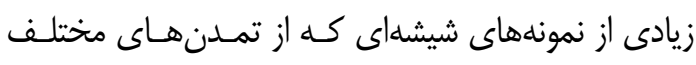

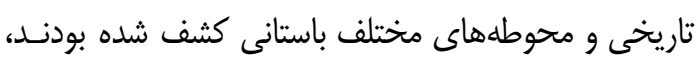

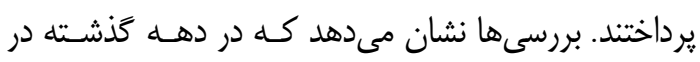

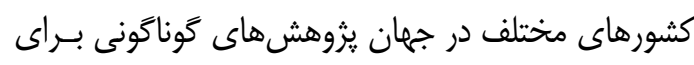

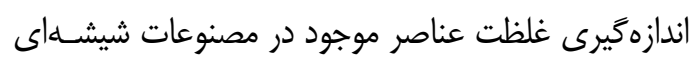

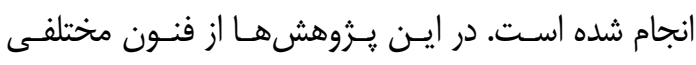

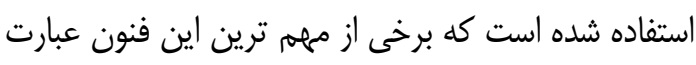

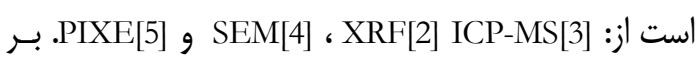

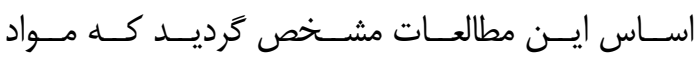

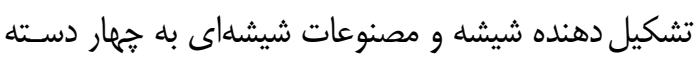
عمده تقسيه مى شوند[6]. () مواد يايه كه ماده اصلى تمام

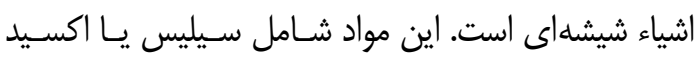

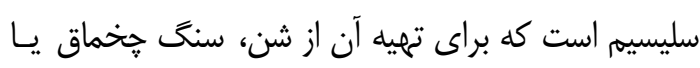
سنگ جينى استفاده مىشود، r) مواد ذوب كننده (كداز آور) كه باعث مىشود نقطه ذوب سيليس كمتر شود. اين مـواد غالباً شامل اكسيد سديم است كه به صورت كربنات سديه، دئه

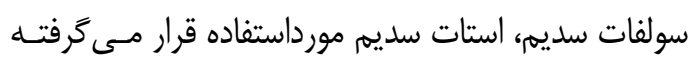

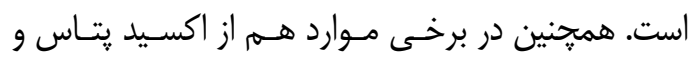

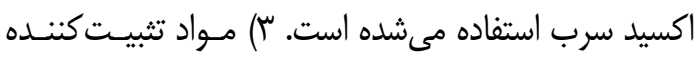

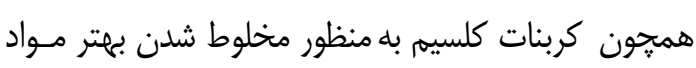

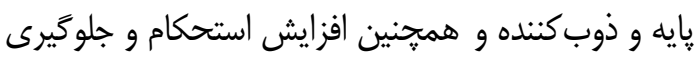

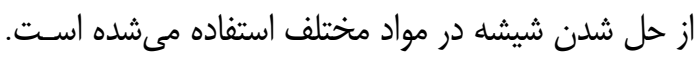

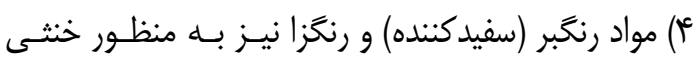

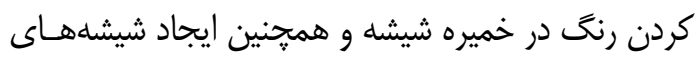

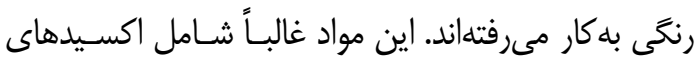

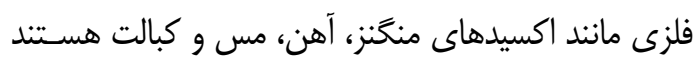

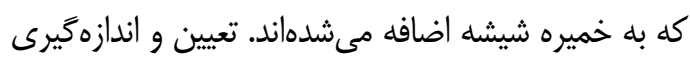

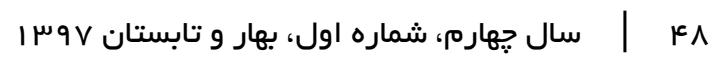


كَياهان بوده و مقايسه نمونههاى اين منـاطق بـا منـاطق ديخر نشاندهنده تفاوت عنصرى تركيبات اسـت و ميـزان

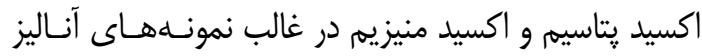
شده ايران نسبت بـه نمونـهـهـاى آنـاليز شــه از سـوريه، فلسطين و عراق بيشتر است. همجنين با بررسى تحقيقات انجامشده بر روى شيشههاى دورههاى اشكانى و ساسـانى در آسياى غربى و ميانرودان مىتوان مشاهده كرد كه بـــــ

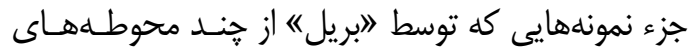
باستانى مربوط به دوره ساسانى انجام شده است] (7)، اخيـراً

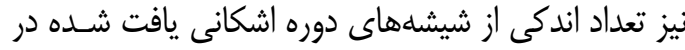

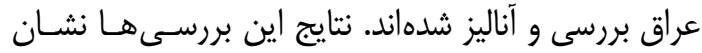
مى دهد كه از 9 نمونه آناليز شده محوطه باستانى سـلوكيه

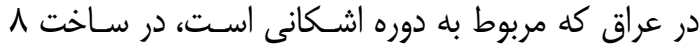
نمونه از ماده معدنى ناترون بلهعنوان كدازآ آور استفاده شـده

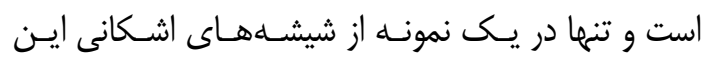

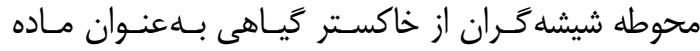
كدازآور استفاده كردهاند[10].

". موقعيت جغرافيايى و ييثينه كاوشهاى

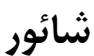

محوطه باستانى كاخ شائور در شهر شوش در جنوب غربى

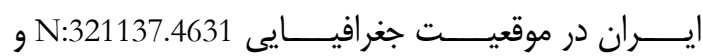

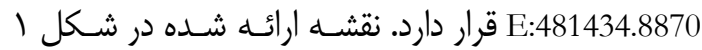
موقعيت اين محوطه را در ايران و ميان رودان و كشورهاى همسايه غربى ايران، و نيز در شوش نشان مىدهد. تبهاى كه كاخ هخامنشسى شـائور را در بركرفتـه، بـين رودخانسه

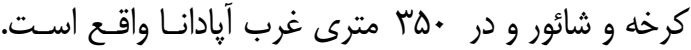

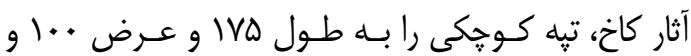

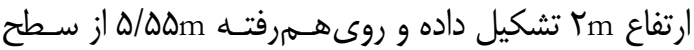
رودخانه شائور بلندتر است[11,12]. ايـن كـاخ تنهـا بنـاى

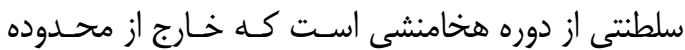

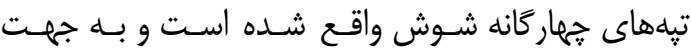

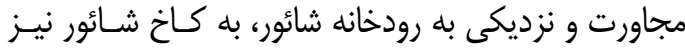

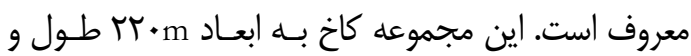

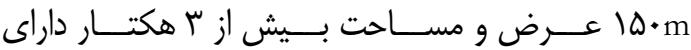
بخشهاى مختلفى است[13].
رفته است، مىتواند نقش تعيين كنندهاى در بررسى فرايند

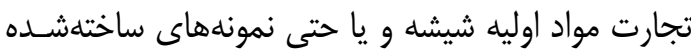
بين ايران و كشورهايى مانند سوريه، عـراق و فلسـئنين

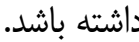

در كام نخست در اين يزوهش نتايج بلهدستـآمــه از

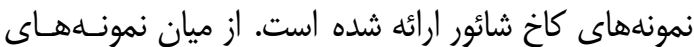

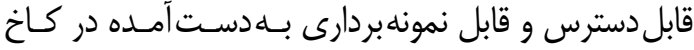

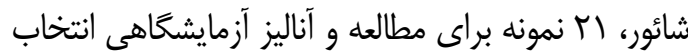

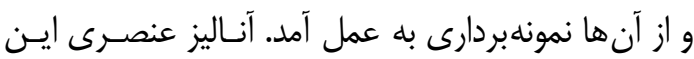

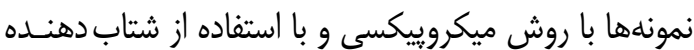
واندوكراف يزوهشكده فيزيك و شـتابخرها در يزوهشـاه علوم و فنون هستهاى انجام كرديد.

\section{r. بيشينه تحقيق}

مطالعاتى توسط "روبرت. اج. بريل" و همكاران او بر روى دئسيف

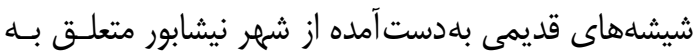
قرن ؤو •ام. (اوايل دوران اسلامى) صورت گرقفتـه اسـت.

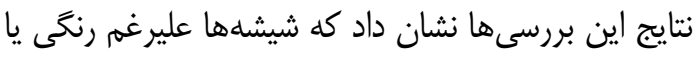
بيىرنحَ بودنشان، ازنظر تركيب عنصــى كـاملاً متفـاوت

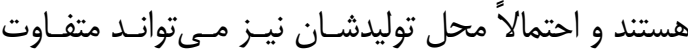
باشد]7]. همجِنين در اين بررسىها نمونههايى از گَركان، رى، همدان و تختسليمان كه غالباً قدمت آنها به آنهائ اوايـل دوران اسلامى برمى گـردد، مـورد آنـاليز و يـرَوهش قـرار

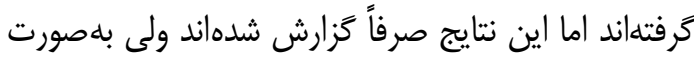
مبسوط بررسى و تحليل نشدهاند. در يزوهش ديخرى كـهـ

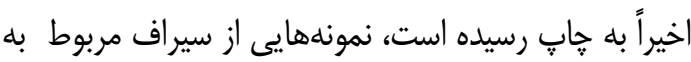

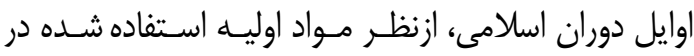
ساخت آن ها و همجنين تعيين محل سـاخت موردبررسى

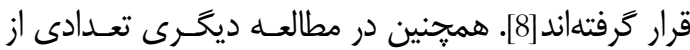

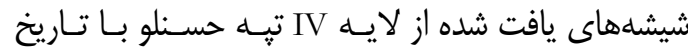

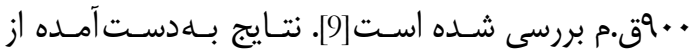
مجموع نمونههاى مطالعه شده از ايران كـه قـدمت آنهـا

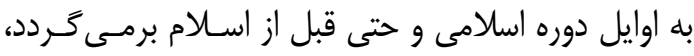

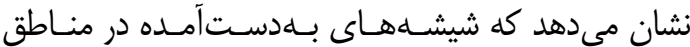
مختلف ايران همكى از نوع شيشهـــاى سـيليكا-سـودا-

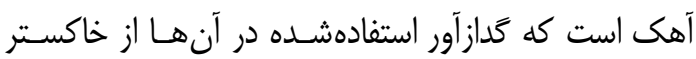




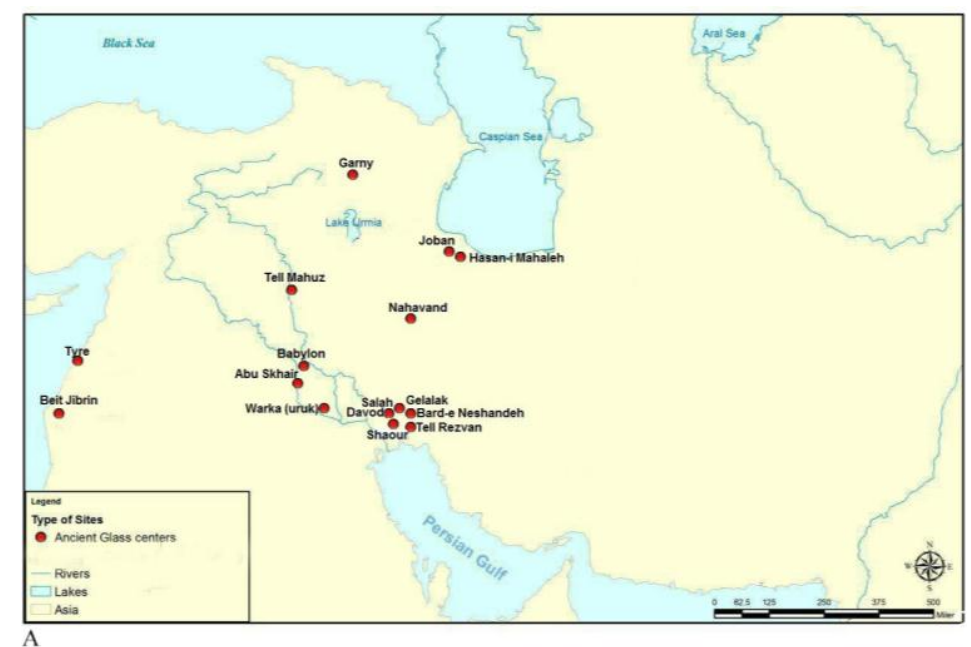

شكل (- الف: موقعيت محوطه شائور در ايران، ميانرودان و كشورهاى همسايه غربى )

Fig. 1a: Map showing the location of the historical sites in Iran, Mesopotamia, and western territories

محوطه ممكن است آثار كهــتـــى وجـود داشـته باشـــ.

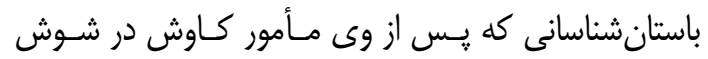

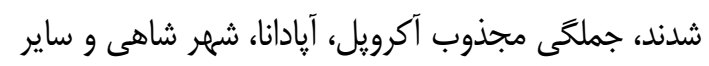

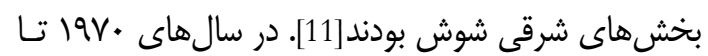
19V9 ام. طى كاوشهايى كه يك تروه از باستانشناسـان

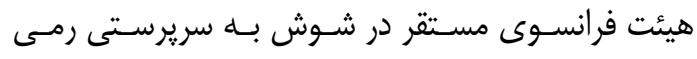
بوشارلا و آدران لابروس با همكارى محمـود كردوانى از

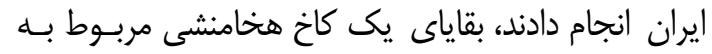

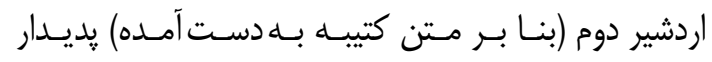
كشت[13] (شكل ا الف-ج).
رودخانه شائور، شهر شوش را به دو قسمت شـرقى و غربى تقسيم مى كند. تيههاى باستانى بهطور كلى در شـرق

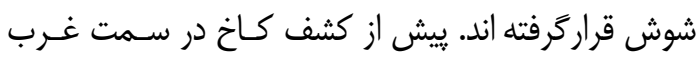
شائور كه به كاخ هخامنشى شائور نام كَارى شــده، كَمـان

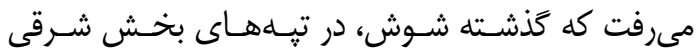

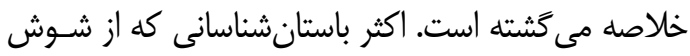

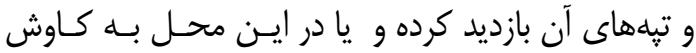

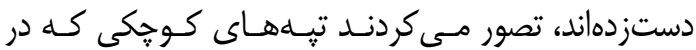

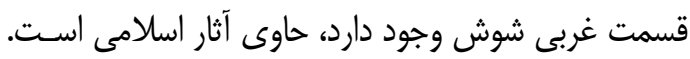
تنها ديولافوا حدس زده بود كـه در طبقـات تحتـانى ايـن

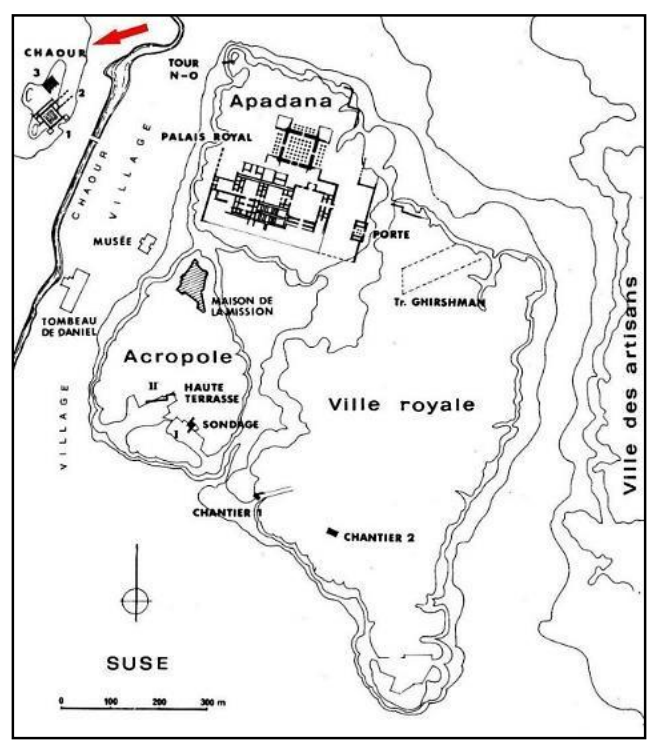

شكل ا-ب: نقشه و موقعيت محوطه كاخ شائور در شوش[11].

Fig. 1b: Location of Shaur Palace at Susa with more details[14] 


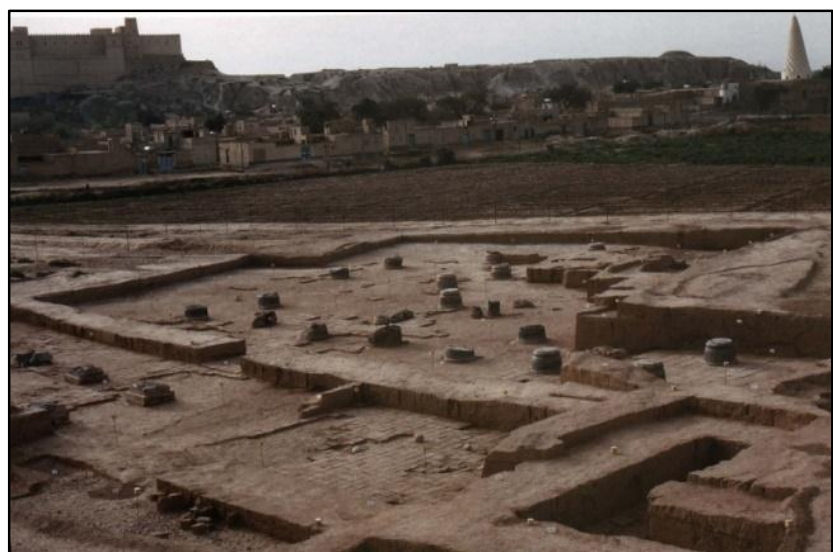

شكل ا-ج: نمايى از محوطه و كاخ شائور

Fig. 1c: View of Shaur palace after excavation

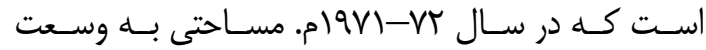

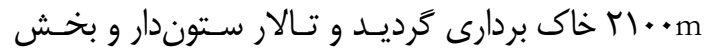
كوجكى از ملحقات آن شناسايى شـد. تـالار تقريبـاً مربـع شكل و داراى \×^ رديف ستون است[12]. يايه ستونهـا،

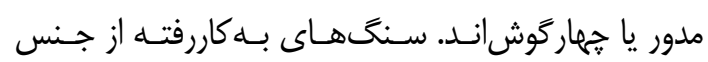

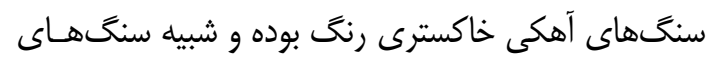

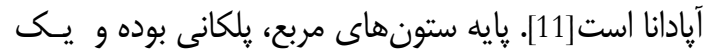

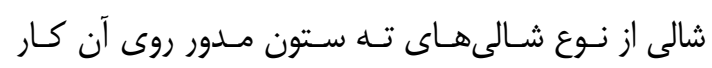

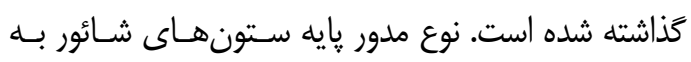
اندازههاى مختلف در مدخل شمالى و غربى آيادانـا، تـالار

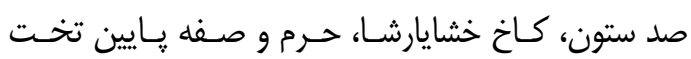
جمشيد وجود دارد[1]].

\section{f أ. معرفى دستساخته هاى شيشهاي كاخ شائور}

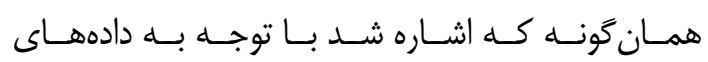

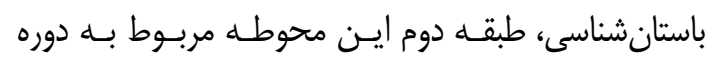

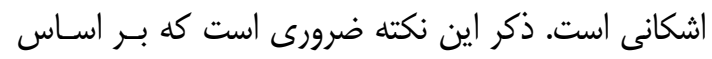
كزارش كاوشگران از كف تالار ستوندار و بلهويزه ترانشـهـ

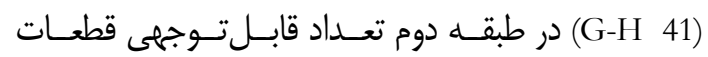

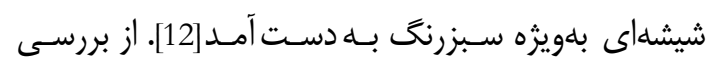

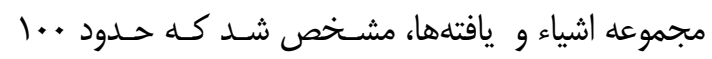

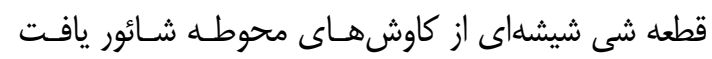

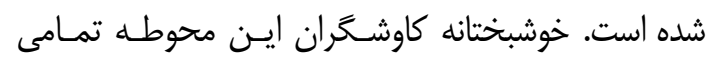

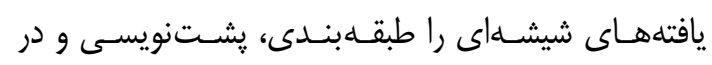

كاوشهاى باستانشناسى شائور از شرق تِـهـ آغـاز و

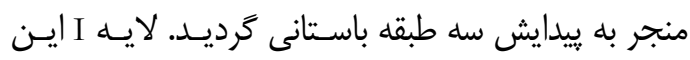

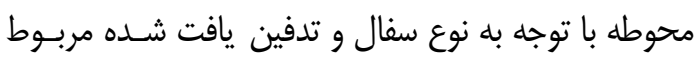

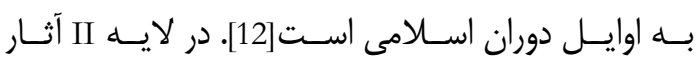
ساختمانى با ديوارهاى خشتى بله دست آمده است و شواهد

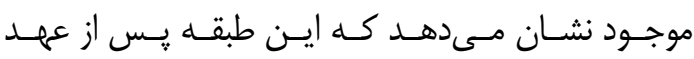
هخامنشيان به وجود آمده است[11]. علاوه بر آن در ايـن

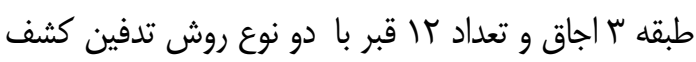

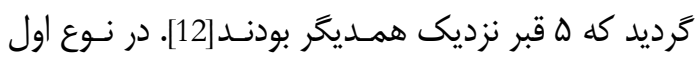

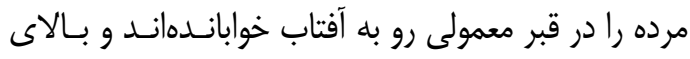

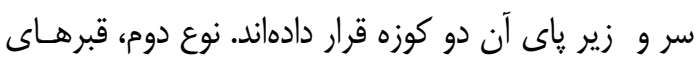

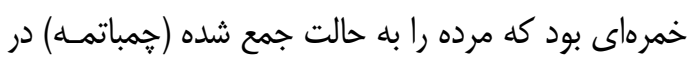

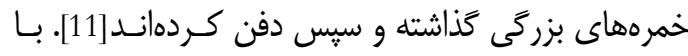

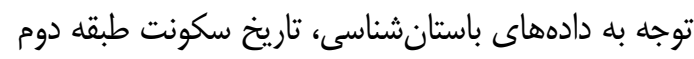

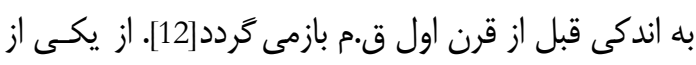

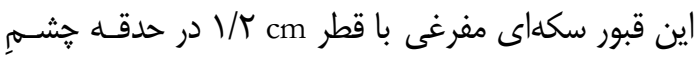
يكى از اسكلتها به دست آمد. در سمت راست روى سكى سكه يادشاه با ريشى انبوه از روبرو نشان دادهشده، دنبالـه كـلاه عمامه مانند وى از يشت سر ديده مىشود. روبروى يادشاه

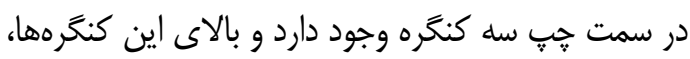

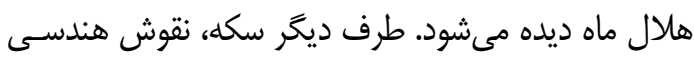

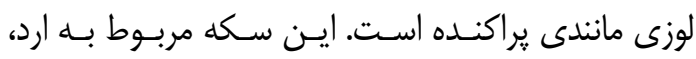

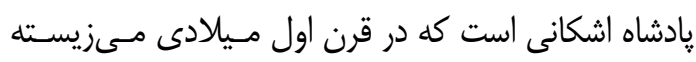
است[11]. لايه III اين محوطه مربوط به كاخ هخامنشى شائور

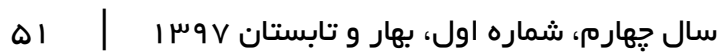


در اين روش آناليز، نمونه موردبررسى تحت تابش يروتون

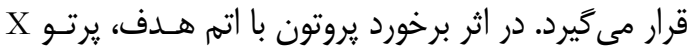

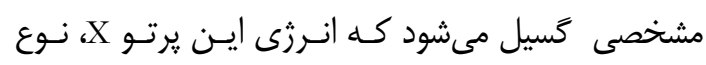

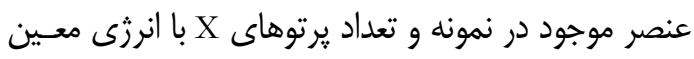
غلظت عنصر در نمونه را مشخص مى كند[15]. با اسـتفاده

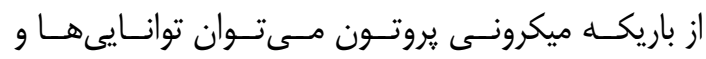

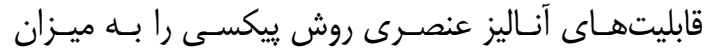

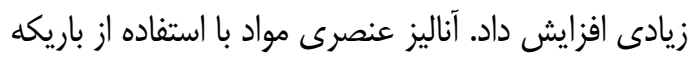

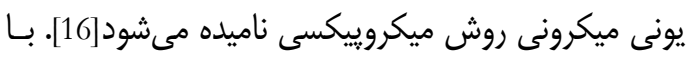

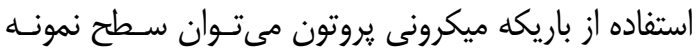

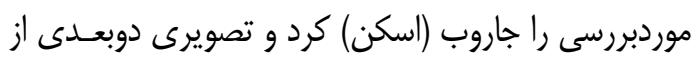

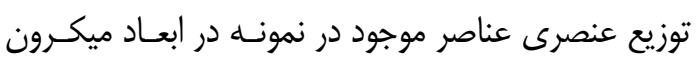

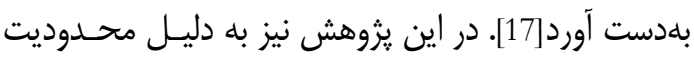

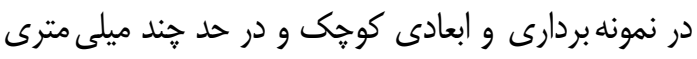

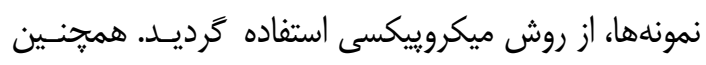

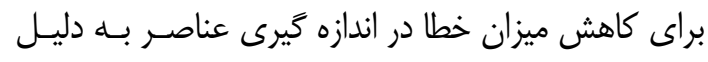

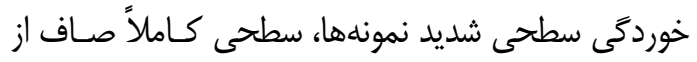

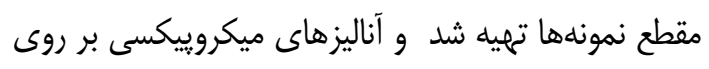

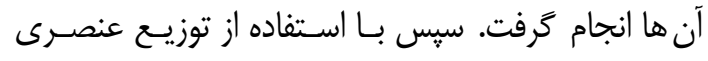

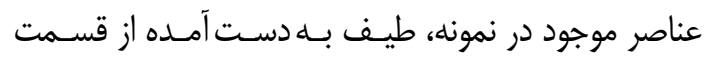

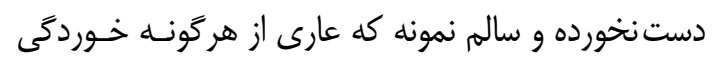

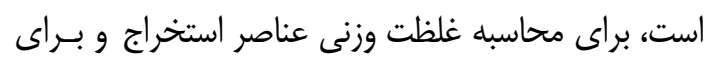

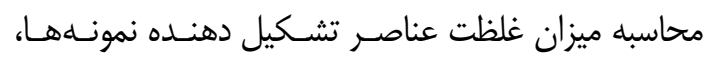

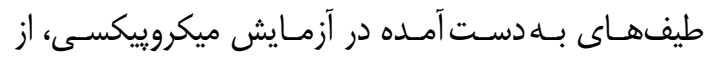

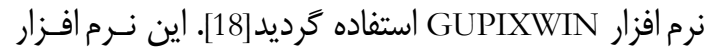

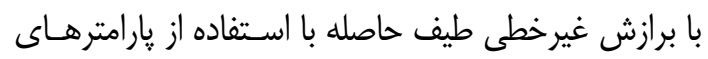

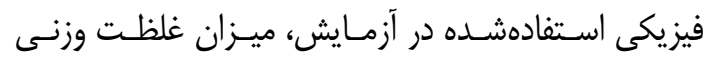

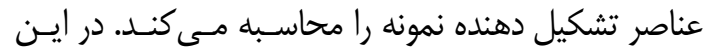

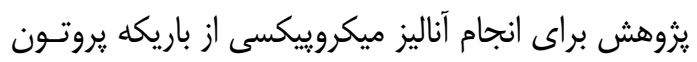

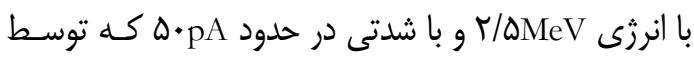

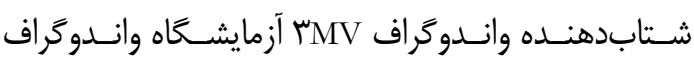
يروهشعاه علوم و فنون هستهاى توليد مىشـود، اسـتفاده

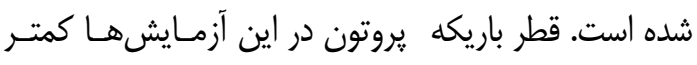

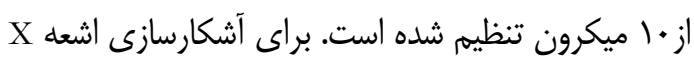

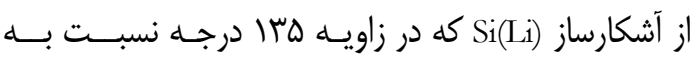

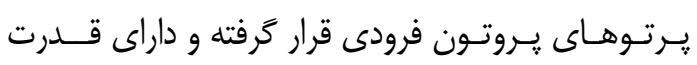

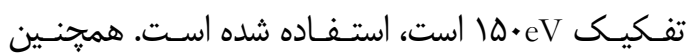

انبارهاى موزه شوش نكَهدارى مى كنند. آثار شيشهاى اين

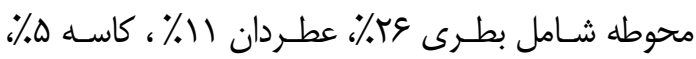

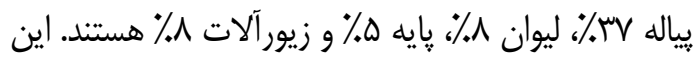

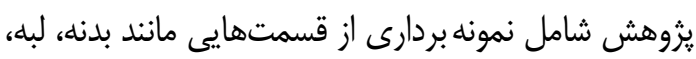

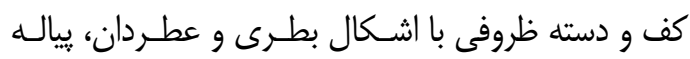

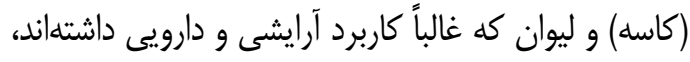

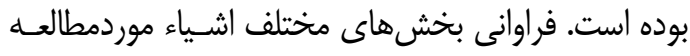

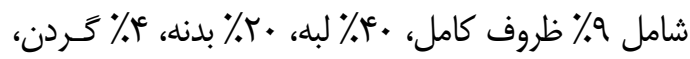

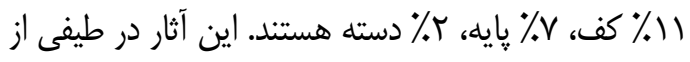

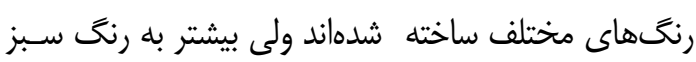

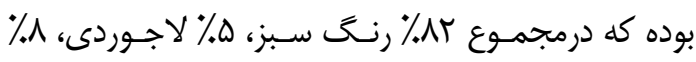

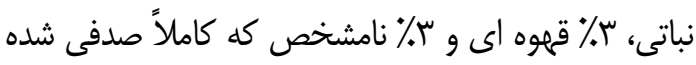
هستند. فن ساخت اشياء شيشهاى در دوره اشكانى بيشـتر

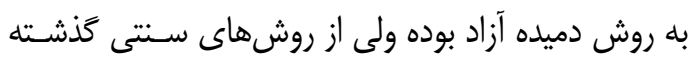

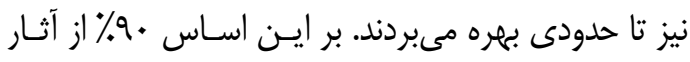

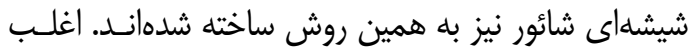

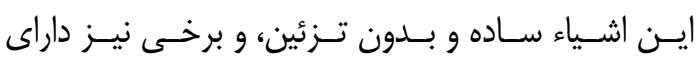

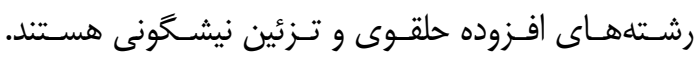

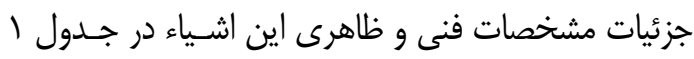

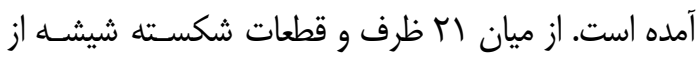

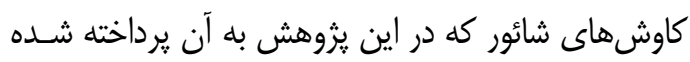

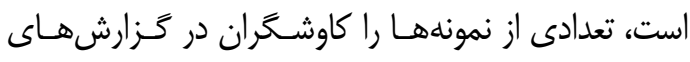

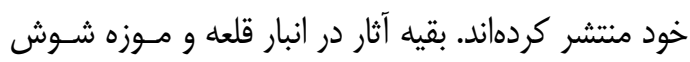

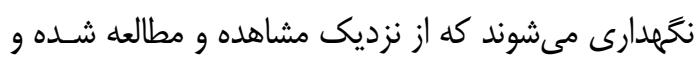

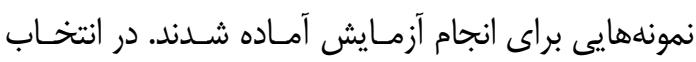

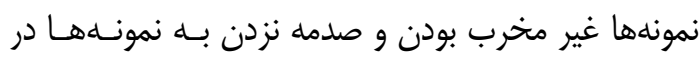

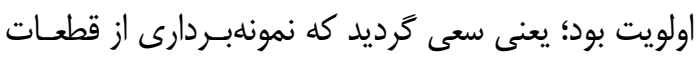

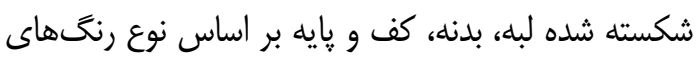

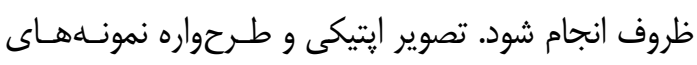
موردبررسى در شكل ז ارائه شده است.

\section{ه. روش و شرايط آناليز ميكروبيكسى}

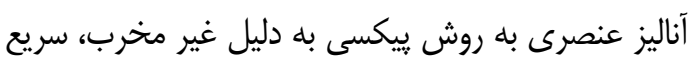
و بس عنصرى بودن، يكى از روشهاى متداول در آنـاليز

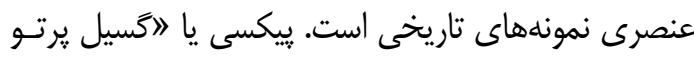

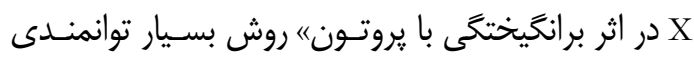

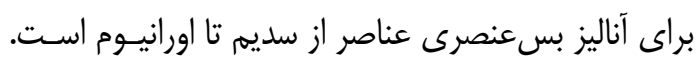

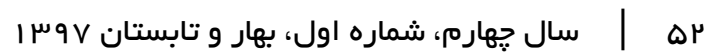


جدول ا: مشخصات فنى و ظاهرى شيشهاى اشكانى كاخ شائور

Table 1: Technical features of Parthian glasses of Shaur Palace

\begin{tabular}{|c|c|c|c|c|c|c|}
\hline $\begin{array}{c}\text { تزئين } \\
\text { Decoration }\end{array}$ & \begin{tabular}{|c|} 
روش ساخت \\
Manufacturin \\
g method
\end{tabular} & $\begin{array}{c}\text { اندازه } \\
\text { Size (cm) }\end{array}$ & $\begin{array}{l}\text { i } \\
\text { Color }\end{array}$ & شكل & $\begin{array}{l}\text { شماره نمونه } \\
\text { Samples } \\
\text { Namber }\end{array}$ & No \\
\hline $\begin{array}{l}\text { ساده } \\
\text { Plain }\end{array}$ & $\begin{array}{c}\text { دميده آزاد } \\
\text { Free Blowing }\end{array}$ & 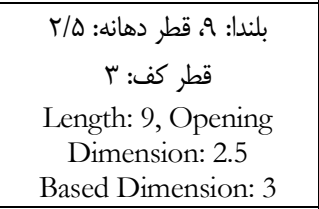 & $\begin{array}{c}\text { سبز } \\
\text { Green }\end{array}$ & $\begin{array}{c}\text { بطرى، لبه به درون تاخورده، بلانه شكل } 1 \text { بلابه } \\
\text { Bottle, outward beveled } \\
\text { rim, pearl-like body }\end{array}$ & СH.71-897.9 & 1 \\
\hline $\begin{array}{c}\text { نوارهاى افزوده دور } \\
\text { دugmented strips } \\
\text { around neck } \\
\text { around }\end{array}$ & $\begin{array}{c}\text { دميده آزاد } \\
\text { Free Blowing }\end{array}$ & 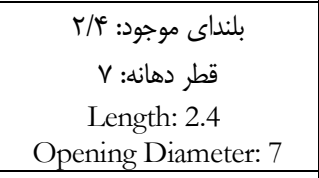 & $\begin{array}{c}\text { سبز } \\
\text { Green }\end{array}$ & $\begin{array}{c}\text { بطرى، لبه به بيرون برگشته، آثار } \\
\text { Bottle, beveled rim, traces } \\
\text { of handles }\end{array}$ & CH.71-782.1 & 2 \\
\hline $\begin{array}{l}\text { ساده } \\
\text { Plain }\end{array}$ & $\begin{array}{c}\text { دميده آزاد } \\
\text { Free Blowing }\end{array}$ & 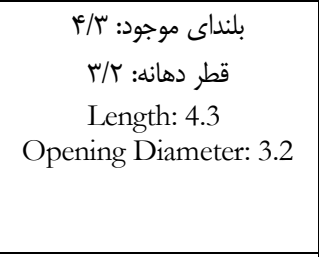 & $\begin{array}{c}\text { سبز } \\
\text { Green }\end{array}$ & 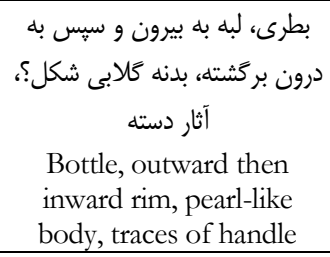 & CH.74-2081-6 & 3 \\
\hline $\begin{array}{l}\text { ساده } \\
\text { Plain } \\
\end{array}$ & \begin{tabular}{|c|} 
دميده آزاد \\
Free Blowing \\
\end{tabular} & بلنداى موجود: س/س & \begin{tabular}{|c|} 
سبز \\
Green \\
\end{tabular} & $\begin{array}{l}\text { بطرى، كردن، عمودى } \\
\text { Bottle, neck, vertical }\end{array}$ & $\begin{array}{l}\text { CH.76- } \\
2902.18\end{array}$ & 4 \\
\hline $\begin{array}{l}\text { ساده } \\
\text { Plain }\end{array}$ & $\begin{array}{c}\text { دميده آزاد } \\
\text { Free Blowing }\end{array}$ & 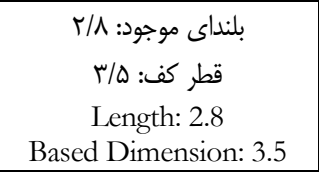 & $\begin{array}{c}\text { سبز } \\
\text { Green }\end{array}$ & 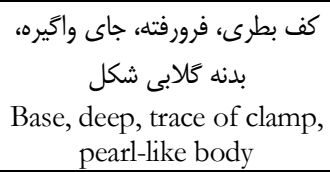 & $\begin{array}{l}\text { CH.76- } \\
2902.14\end{array}$ & 5 \\
\hline ساده & $\begin{array}{c}\text { دميده آزاد } \\
\text { Free Blowing }\end{array}$ & 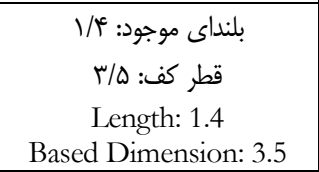 & $\begin{array}{c}\text { سبز } \\
\text { Green }\end{array}$ & 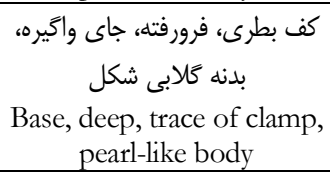 & CH.76-2883.1 & 6 \\
\hline $\begin{array}{c}\text { نوارهاى افزوده حلقوى } \\
\text { Augmented } \\
\text { circular strips }\end{array}$ & $\begin{array}{c}\text { Free Blowing } \\
\text { Fميده آزاد }\end{array}$ & 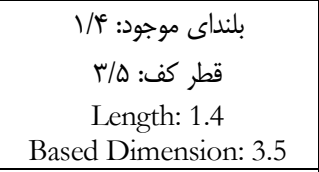 & سبز & 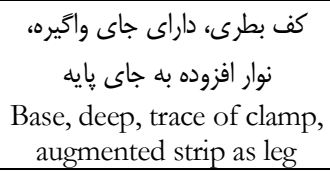 & CH.73-1142.2 & 7 \\
\hline 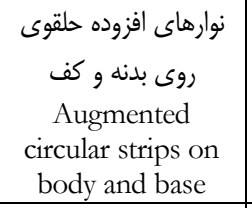 & $\begin{array}{c}\text { دميده آزاد } \\
\text { Free Blowing }\end{array}$ & 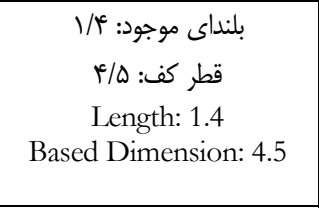 & $\begin{array}{c}\text { سبز } \\
\text { Green }\end{array}$ & $\begin{array}{c}\text { كف بطرى، داراى جاى واكيره، نوار افزوده به بايه } \\
\text { Base, trace of clamp, } \\
\text { augmented strip as leg }\end{array}$ & CH.70-273.1 & 8 \\
\hline $\begin{array}{c}\text { نوار افزوده به جاى پايه } \\
\text { Augmented strip as } \\
\text { leg }\end{array}$ & $\begin{array}{c}\text { دميده آزاد } \\
\text { Free Blowing }\end{array}$ & 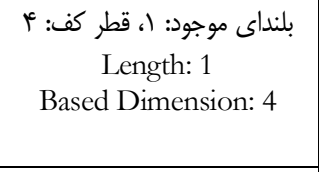 & \begin{tabular}{c|} 
Green \\
Green
\end{tabular} & 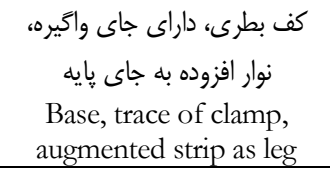 & CH.70-187.1 & 9 \\
\hline $\begin{array}{c}\text { نوار افزوده به جاى پايه } \\
\text { Augmented strip as } \\
\text { leg }\end{array}$ & $\begin{array}{c}\text { دميده آزاد } \\
\text { Free Blowing }\end{array}$ & 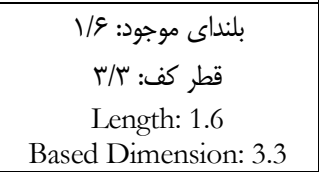 & $\begin{array}{c}\text { سبز } \\
\text { Green }\end{array}$ & 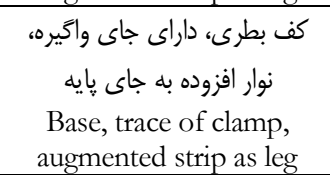 & CH.73-1189.1 & 10 \\
\hline $\begin{array}{l}\text { ساده } \\
\text { Plain }\end{array}$ & $\begin{array}{c}\text { دميده آزاد } \\
\text { Free Blowing }\end{array}$ & 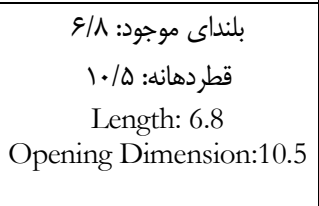 & $\begin{array}{l}\text { نباتى } \\
\text { light } \\
\text { buff }\end{array}$ & $\begin{array}{c}\text { كاسه، لبه اندكى به درون بركشته، بدنه نيمكروى كشيده } \\
\text { Bowl, semi internaly } \\
\text { curved rim, semi round } \\
\text { tall body }\end{array}$ & CH.71-820.1 & 11 \\
\hline
\end{tabular}

ادامه جلول در صفحه بعد 


\begin{tabular}{|c|c|c|c|c|c|c|}
\hline $\begin{array}{c}\text { تزئين } \\
\text { Decoration }\end{array}$ & $\begin{array}{c}\text { روش ساخت } \\
\text { Manufacturin } \\
\text { g method }\end{array}$ & $\begin{array}{c}\text { اندازه } \\
\text { Size (cm) }\end{array}$ & $\begin{array}{l}\text { Color } \\
\text { Cor }\end{array}$ & شكل & $\begin{array}{l}\text { شماره نمونه } \\
\text { Samples } \\
\text { Namber }\end{array}$ & $\mathrm{No}$ \\
\hline $\begin{array}{l}\text { ساده } \\
\text { Plain }\end{array}$ & $\begin{array}{c}\text { دميده آزاد } \\
\text { Free Blowing }\end{array}$ & 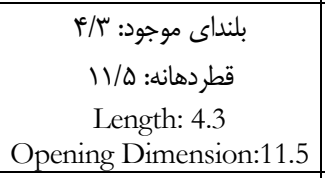 & $\begin{array}{c}\text { سبز } \\
\text { Green }\end{array}$ & $\begin{array}{c}\text { كاسه، لبه تا خورده به بيرون ، بدنه } \\
\text { Bowl, outwardly curved } \\
\text { rim, oblique body } \\
\text { مايل }\end{array}$ & CH.76-2902.4 & 12 \\
\hline $\begin{array}{c}\text { نوارافزوده حلقوى زير لبه } \\
\text { Augmented } \\
\text { circular strip under } \\
\text { rim }\end{array}$ & $\begin{array}{c}\text { دميده آزاد } \\
\text { Free Blowing }\end{array}$ & 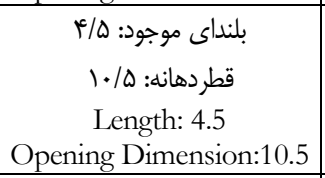 & $\begin{array}{c}\text { سبز } \\
\text { Green }\end{array}$ & $\begin{array}{c}\text { يياله، لبه تا خورده به بيرون، بدنه } \\
\text { مايل } \\
\text { Bowl, outwardly curved } \\
\text { rim, oblique body }\end{array}$ & بدون كد & 13 \\
\hline $\begin{array}{c}\text { نوارافزوده حلقوى زير لبه } \\
\text { Augmented } \\
\text { circular strip under } \\
\text { rim }\end{array}$ & $\begin{array}{c}\text { دميده آزاد } \\
\text { Free Blowing }\end{array}$ & 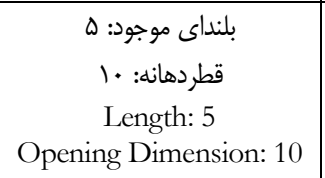 & $\begin{array}{c}\text { سبز } \\
\text { Green }\end{array}$ & $\begin{array}{c}\text { يباله، لبه تا خورده به بيرون، بدنه } \\
\text { مايل } \\
\text { Bowl, outwardly curved } \\
\text { rim, oblique body }\end{array}$ & CH.76-2905 & 14 \\
\hline $\begin{array}{c}\text { نوارافزوده حلقوى زير لبه } \\
\text { Augmented } \\
\text { circular strip under } \\
\text { rim }\end{array}$ & $\begin{array}{c}\text { دميده آزاد } \\
\text { Free Blowing }\end{array}$ & 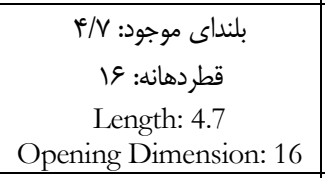 & $\begin{array}{c}\text { سبز } \\
\text { Green }\end{array}$ & $\begin{array}{c}\text { يباله، لبه تا خورده به بيرون، بدنه } \\
\text { Bowl, outwardly curved } \\
\text { rim, oblique body } \\
\text { rimed }\end{array}$ & CH.76-2902.9 & 15 \\
\hline $\begin{array}{c}\text { نوارافزوده حلقوى زير لبه } \\
\text { Augmented } \\
\text { circular strip under } \\
\text { rim }\end{array}$ & $\begin{array}{c}\text { دميده آزاد } \\
\text { Free Blowing }\end{array}$ & 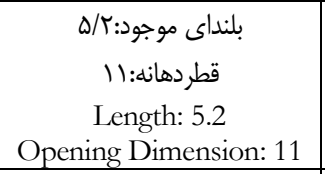 & $\begin{array}{c}\text { سبز } \\
\text { Green }\end{array}$ & 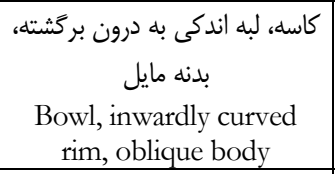 & CH.76-2902.2 & 16 \\
\hline 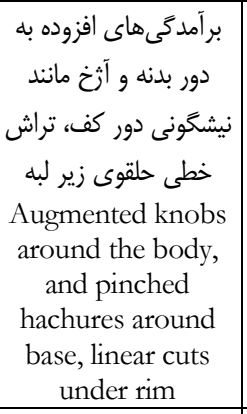 & $\begin{array}{c}\text { دميده آزاد } \\
\text { Free Blowing }\end{array}$ & 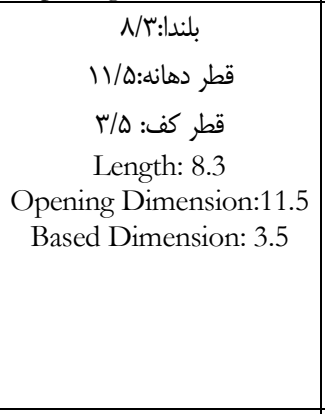 & $\begin{array}{c}\text { سبز } \\
\text { Green }\end{array}$ & $\begin{array}{c}\text { كاسه، لبه بيرون، بدنه زنخى شكل شانس } \\
\text { Bowl, outwardly curved } \\
\text { rim, bell-like body }\end{array}$ & CH.71-781.1 & 17 \\
\hline $\begin{array}{l}\text { ساده } \\
\text { Plain }\end{array}$ & $\begin{array}{l}\text { دميده آزاد } \\
\text { Free Blowing }\end{array}$ & $\begin{array}{c}\text { ب/T:بلنداى موجود: } 8.2 \\
\text { Length }\end{array}$ & $\begin{array}{c}\text { سبز } \\
\text { Green }\end{array}$ & $\begin{array}{c}\text { يباله، بدنه مايل و خميده } \\
\text { Bowl, oblique and curved } \\
\text { body }\end{array}$ & $\begin{array}{l}\text { CH.76- } \\
2902.17\end{array}$ & 18 \\
\hline $\begin{array}{c}\text { نوارهاى افزوده نامنظم } \\
\text { Irregular } \\
\text { augmented strips }\end{array}$ & $\begin{array}{c}\text { دميده آزاد } \\
\text { Free Blowing }\end{array}$ & 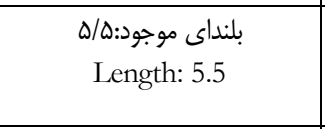 & $\begin{array}{c}\text { سبز } \\
\text { Green }\end{array}$ & $\begin{array}{c}\text { ييالd؟، بدنه نيمكروى } \\
\text { Bowl?, semicircular body }\end{array}$ & СH.70-345.1 & 19 \\
\hline $\begin{array}{l}\text { ساده } \\
\text { Plain }\end{array}$ & $\begin{array}{c}\text { دميده آزاد } \\
\text { Free Blowing }\end{array}$ & 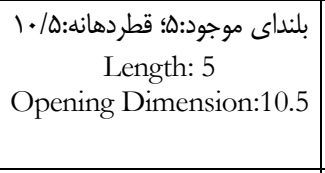 & $\begin{array}{c}\text { سبز } \\
\text { Green }\end{array}$ & $\begin{array}{c}\text { ليوان، لبه اندكى به بيرون بركشته، عمودى } \\
\text { Beaker, little outwardly } \\
\text { curved rim, vertical body } \\
\text { curtical }\end{array}$ & CH.71-812.1 & 20 \\
\hline $\begin{array}{c}\text { نوار افزوده حلقوى تخت زير لبه } \\
\text { Circular augmented } \\
\text { strips under rim } \\
\end{array}$ & $\begin{array}{c}\text { Free Blowing } \\
\text { دميده آزاد }\end{array}$ & 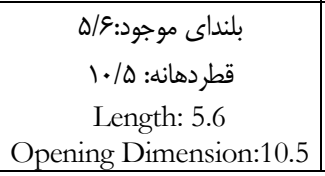 & $\begin{array}{l}\text { نباتى } \\
\text { light } \\
\text { buff }\end{array}$ & $\begin{array}{c}\text { ليوان، لبه اندكى به بيرون برگشته، } \\
\text { Beaker, little outwardly } \\
\text { curved rim, knob body } \\
\text { culim } \\
\end{array}$ & CH.71-817.1 & 21 \\
\hline
\end{tabular}




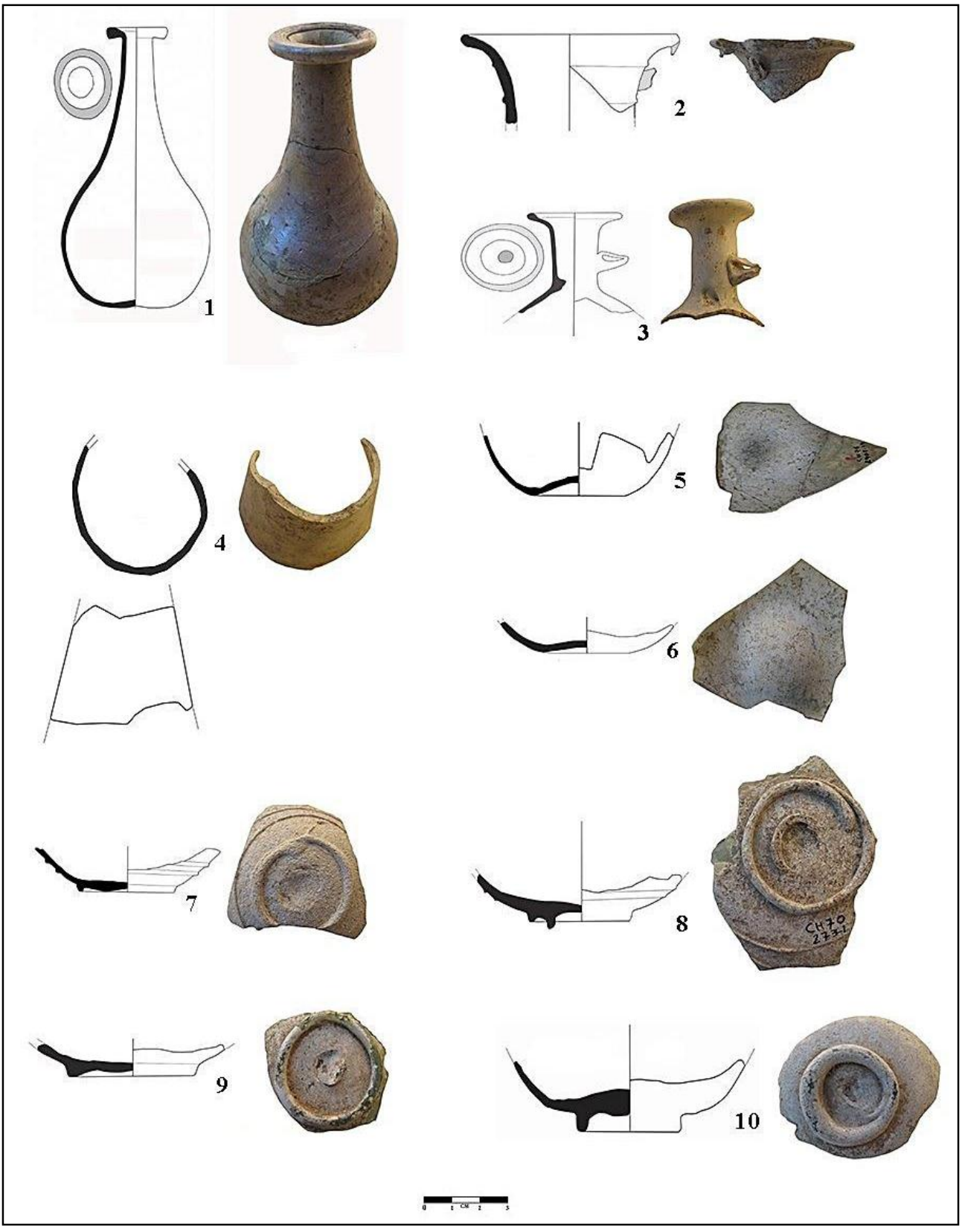

شكل r: تصاوير و طرحهاى نمونههاى آناليز شده

Fig. 2: Photos and drawing of analyzed samples (continued)

دقت اندازه گيرى عناصر اصلى كمتر از هـ و براى عناصـر

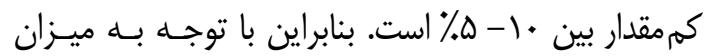

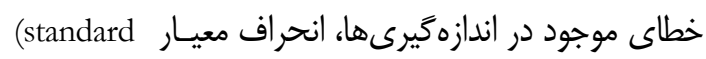
deviation)

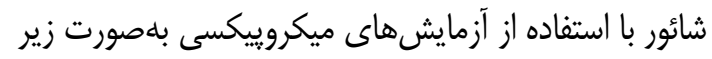
اسـتـ: ، $\mathrm{TiO}_{2}: 0.003 \%$ ، $\mathrm{CaO}: 0.04 \% ، \mathrm{~K}_{2} \mathrm{O}: 0.02 \% \mathrm{SiO}_{2}: 0.15 \%$ . $\mathrm{Fe}_{2} \mathrm{O}_{3}: 0.016 \%$ g $\mathrm{MnO}: 0.006 \%$
در اين آزمايشها از سيستم ميكـرو باريكـهـ و جمـع آورى

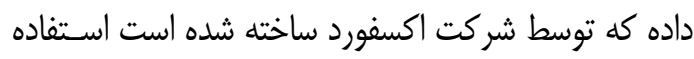

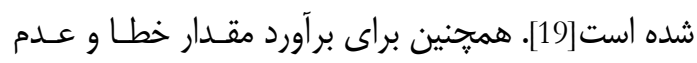

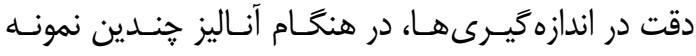

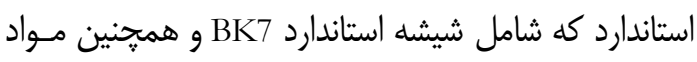
خالصى مانند

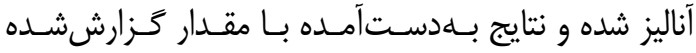

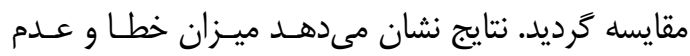




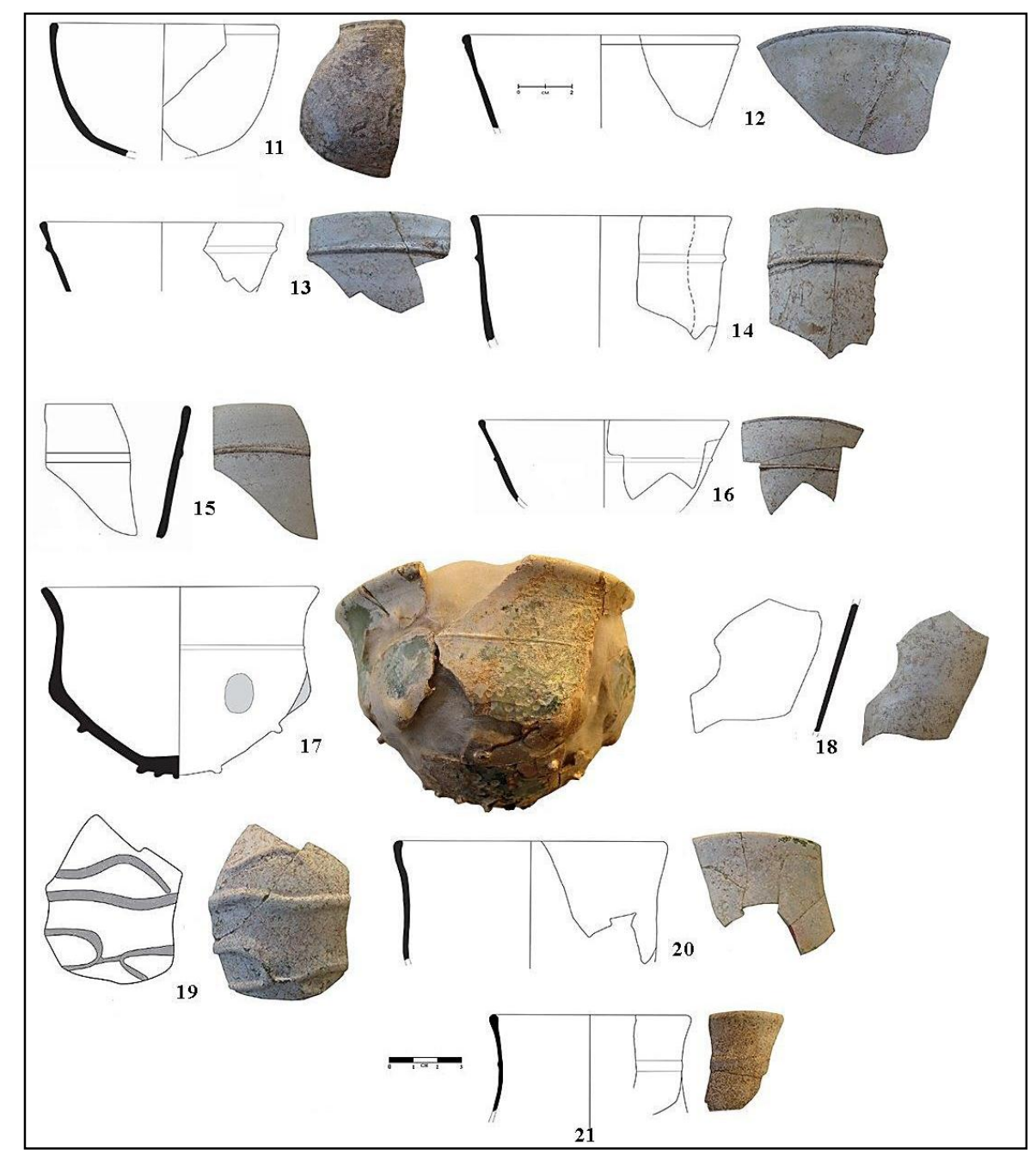

ادامه شكل r: تصاوير و طرحهاى نمونههاى آناليز شده

Fig. 2: Photos and drawing of analyzed samples (continue)

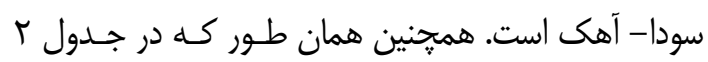

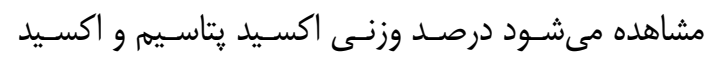

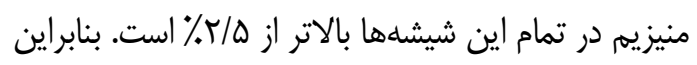

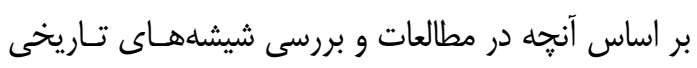
توسط يزوهشكَران متداول است[20] درصورتى كـهـ ميـزان

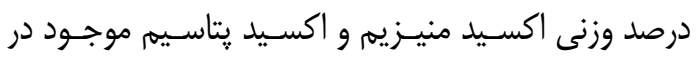

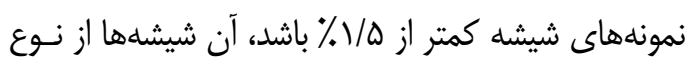

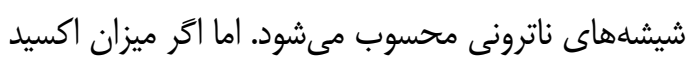

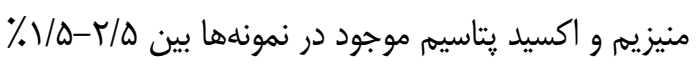

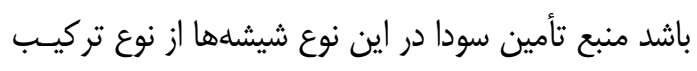

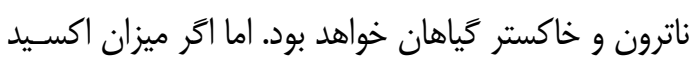

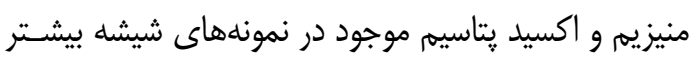

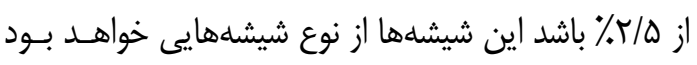

\section{و. نتايج و بحث يافتهها}

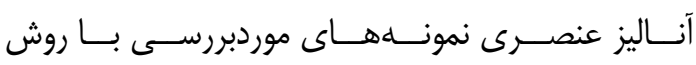

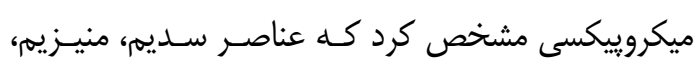

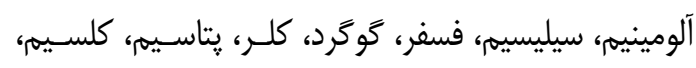

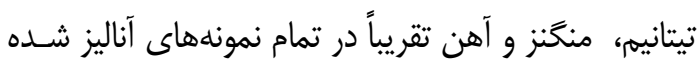

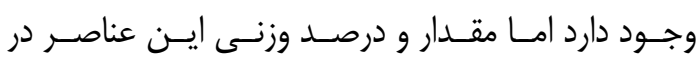

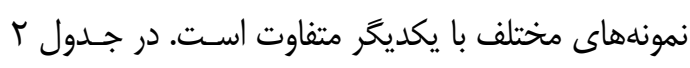

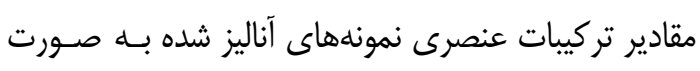

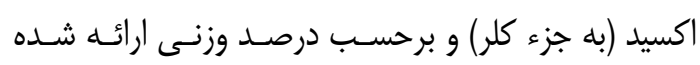

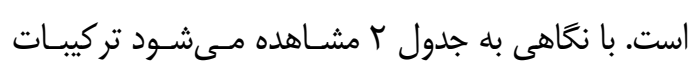

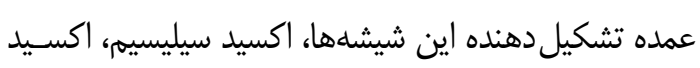

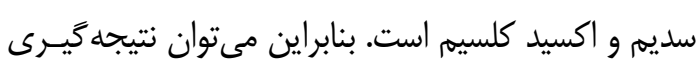

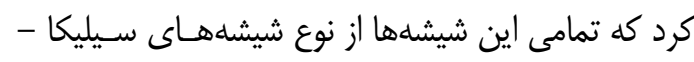

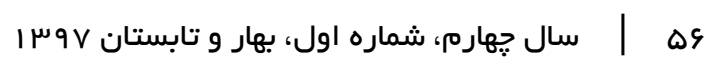


جدول r: مقادير عناصر موجود در نمونههاى آناليز شده بلهصورت اكسيد و برحسب درصد وزنى

Table 2: The results of elemental composition in analyzed samples in weight percent (wt. \%) as oxides form

\begin{tabular}{|c|c|c|c|c|c|c|c|c|c|c|c|c|c|}
\hline Samples & $\mathrm{Na}_{2} \mathrm{O}$ & $\mathrm{MgO}$ & $\mathrm{Al}_{2} \mathrm{O}_{3}$ & $\mathrm{SiO}_{2}$ & $\mathrm{P}_{2} \mathrm{O}_{5}$ & $\mathrm{SO}_{3}$ & $\mathrm{Cl}$ & $\mathrm{K}_{2} \mathrm{O}$ & $\mathrm{CaO}$ & $\mathrm{TiO}_{2}$ & $\mathrm{Cr}_{2} \mathrm{O}_{3}$ & $\mathrm{MnO}$ & $\mathrm{Fe}_{2} \mathrm{O}_{3}$ \\
\hline S1 & 17.12 & 2.54 & 3.22 & 69.17 & 0.53 & 0.30 & 0.75 & 2.49 & 2.80 & 0.14 & n.d & 0.04 & 0.91 \\
\hline S2 & 16.27 & 3.77 & 3.32 & 63.00 & 0.37 & 0.26 & 0.78 & 3.97 & 6.97 & 0.17 & n.d & 0.05 & 1.01 \\
\hline S3 & 15.54 & 3.86 & 3.59 & 62.99 & 0.40 & 0.16 & 0.88 & 3.56 & 7.58 & 0.17 & 0.03 & 0.04 & 1.11 \\
\hline S4 & 16.06 & 4.98 & 2.07 & 63.68 & 0.41 & 0.18 & 0.92 & 3.61 & 6.97 & 0.06 & 0.04 & 0.04 & 0.64 \\
\hline S5 & 14.88 & 4.38 & 3.2 & 64.41 & 0.42 & 0.24 & 0.87 & 3.94 & 6.73 & 0.07 & 0.02 & 0.03 & 0.68 \\
\hline S6 & 16.03 & 4.98 & 2.89 & 63.37 & 0.50 & 0.28 & 0.88 & 3.60 & 6.46 & 0.10 & n.d & 0.04 & 0.83 \\
\hline S7 & 17.31 & 4.10 & 2.65 & 63.46 & 0.62 & 0.23 & 1.10 & 3.02 & 6.64 & 0.13 & n.d & 0.03 & 0.65 \\
\hline S8 & 15.74 & 4.50 & 2.78 & 63.45 & 0.40 & 0.30 & 0.86 & 3.43 & 7.15 & 0.1 & n.d & 0.06 & 0.74 \\
\hline S9 & 13.79 & 2.60 & 6.01 & 64.20 & 0.38 & 0.32 & 0.91 & 3.50 & 6.46 & 0.11 & 0.14 & 0.05 & 1.34 \\
\hline S10 & 15.31 & 3.27 & 3.25 & 64.45 & 0.42 & 0.23 & 0.93 & 4.04 & 6.87 & 0.16 & n.d & 0.04 & 0.93 \\
\hline S11 & 15.65 & 4.50 & 3.43 & 63.66 & 0.48 & 0.23 & 0.76 & 2.23 & 7.38 & 0.13 & n.d & 0.65 & 0.83 \\
\hline $\mathrm{S} 12$ & 16.49 & 4.88 & 2.58 & 63.42 & 0.51 & 0.21 & 0.82 & 3.80 & 6.53 & 0.05 & 0.04 & 0.03 & 0.61 \\
\hline S13 & 15.83 & 4.62 & 3.44 & 62.92 & 0.26 & 0.25 & 0.89 & 3.63 & 7.03 & 0.07 & n.d & 0.06 & 0.79 \\
\hline $\mathrm{S} 14$ & 14.85 & 4.96 & 2.51 & 64.81 & 0.72 & 0.28 & 0.85 & 3.90 & 6.44 & 0.07 & n.d & 0.03 & 0.57 \\
\hline S15 & 16.57 & 4.82 & 2.95 & 63.13 & 0.45 & 0.31 & 0.77 & 3.59 & 6.57 & 0.07 & 0.04 & 0.03 & 0.63 \\
\hline S16 & 15.77 & 4.64 & 2.87 & 64.52 & 0.48 & 0.28 & 0.83 & 3.74 & 6.12 & 0.06 & 0.02 & 0.02 & 0.54 \\
\hline S17 & 13.77 & 3.86 & 6.90 & 64.09 & n.d & $\begin{array}{c}0.24 \\
\end{array}$ & 0.68 & 2.85 & 5.21 & 0.18 & n.d & 0.06 & 1.52 \\
\hline S18 & 15.80 & 4.83 & 2.18 & 64.20 & 0.36 & 0.26 & 0.87 & 3.92 & 6.82 & 0.07 & n.d & 0.03 & 0.66 \\
\hline S19 & 15.66 & 3.27 & 3.36 & 65.08 & 0.38 & 0.22 & $\begin{array}{l}0.82 \\
\end{array}$ & 3.62 & 6.46 & 0.16 & 0.03 & 0.03 & 0.86 \\
\hline S20 & 15.41 & 3.33 & 3.45 & 63.74 & 0.51 & 0.27 & 0.87 & 3.51 & 7.59 & 0.18 & n.d & 0.04 & 1.05 \\
\hline S21 & n.d & 0.96 & 6.37 & 81.55 & 0.76 & 0.72 & 0.76 & 4.78 & 0.77 & 0.38 & n.d & 0.09 & 2.19 \\
\hline
\end{tabular}

تشكيل دهنده تمام اشياء شيشـهاى نـوع سـيليكا ســودا-

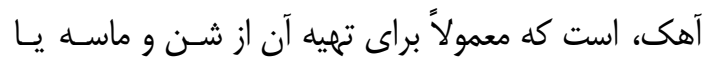

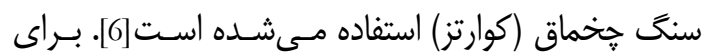
بررسى خلوص منابع سيليس استفادهشده در فرايند ساخت إنتانت

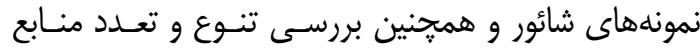

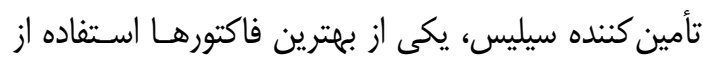

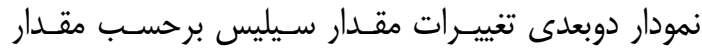

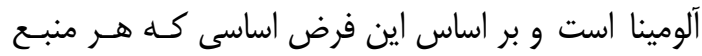

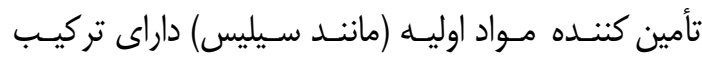

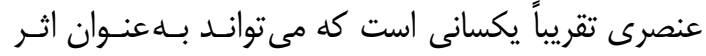
انغشت و نشاندهنده خصوصيات منابع اوليه باشد، اسـتوار

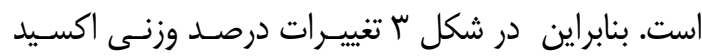
سيليسيم $\left(\mathrm{SiO}_{2}\right)$ برحسب اكسيد آلومينيم

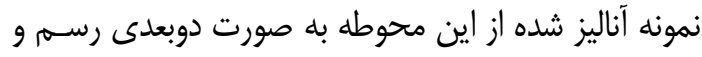

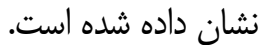

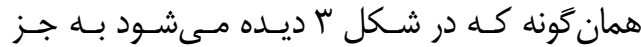

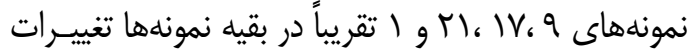

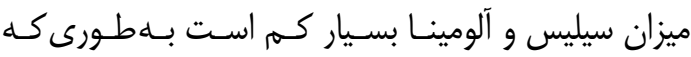

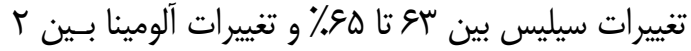

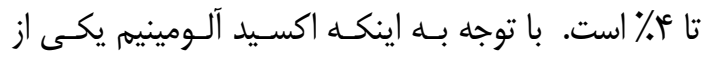

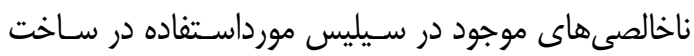

كه منبع تأمين اكسيد سديم آن خاكستر حاصل از گياهان رشد يافته در خاكهاى شـور بـوده اسـت. بنـابراين تمـام

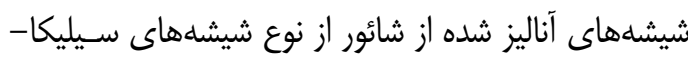

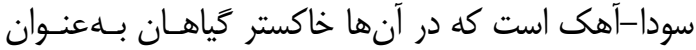
ماده اوليه سودا بهكـار رفتـه اسـت. همجنــين نتـايج ايسن

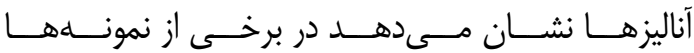
(S3,S5,S11,S16) عنصـر استرانسيم در محسدوده • / •-

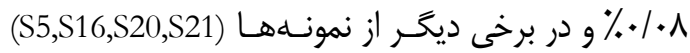

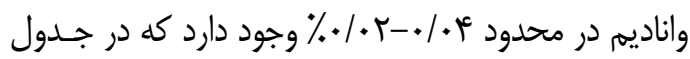

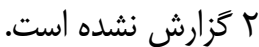

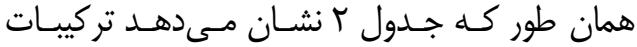

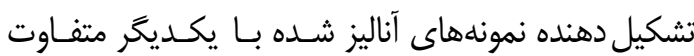

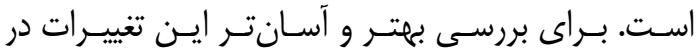
نمونههاى مختلف و بهدسـت آوردن اطلاعـات كامـل درد مورد مواد اوليه و خام مورداستفاده در ساخت اين شيشهها كه از نوع سيليكا-سودا-آهك هستند، استفاده از تصـاوير

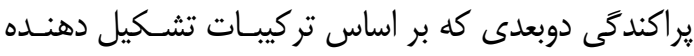
نمونهها رسم مى شيوند، بسيار مفيد و كارآ آمد هستند.

\section{צ-ا. بر رسى منابع تأمين سيليس}

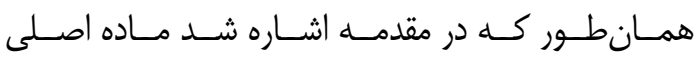

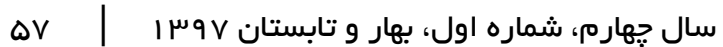




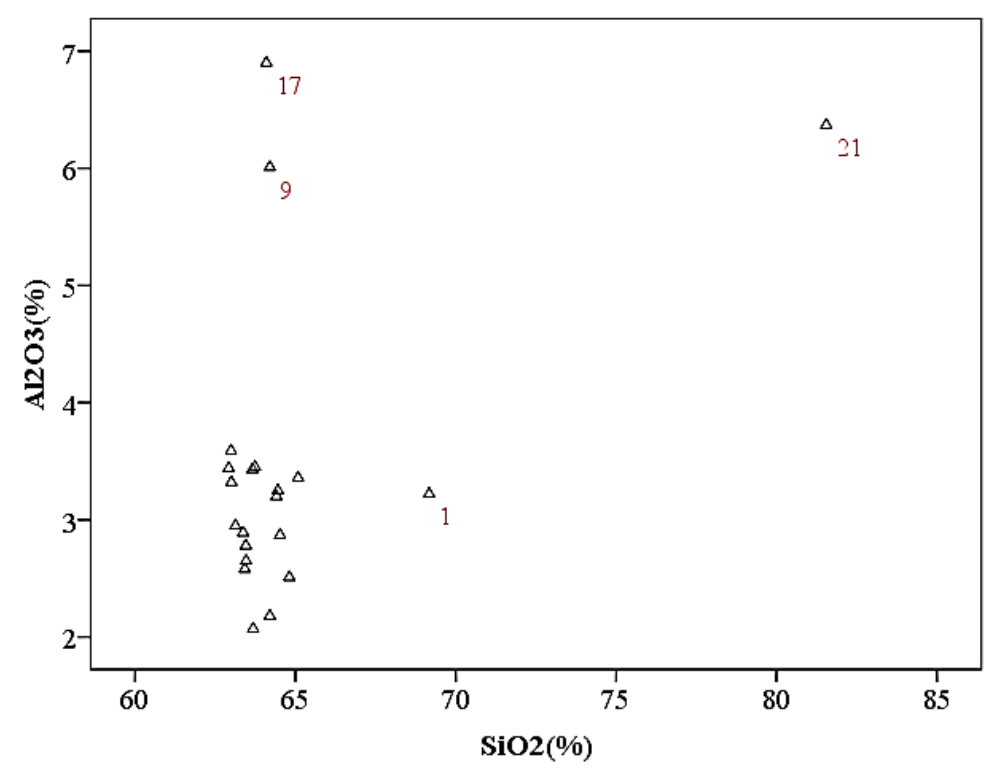

شكل ": تغييرات درصد وزنى اكسيد سيليسيمى (سيليس) برحسب اكسيد آلومينيم (آلومينا) در نمونههاى آناليز شده محوطه شائور

Fig. 3: Scatter plot of wt. \% of $\mathrm{SiO}_{2}$ versus $\mathrm{Al}_{2} \mathrm{O}_{3}$ in analyzed sample from shaur

با بقيه نمونهها باه مقدار قابل توجهى تفاوت دارد، مشخص

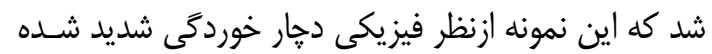

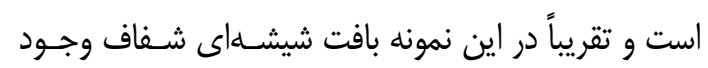

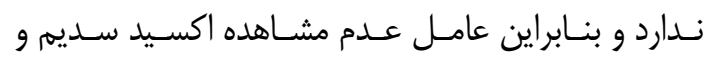

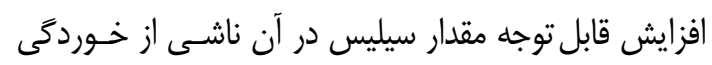

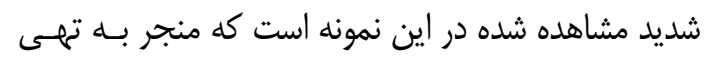

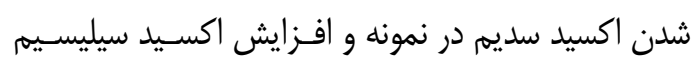
شده است[23]. همجنين نمونه ا كه درصد وزنسى آلومينـا

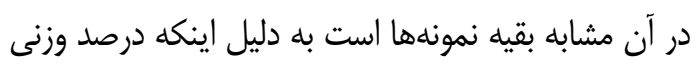
سيليس در آن مقدارى بالاتر است، از ديخر نمونهها متمايز است و احتمالاً علت اين تمايز مربوط به مواد اوليـهـ ديخــر

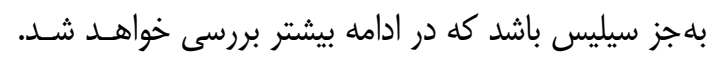

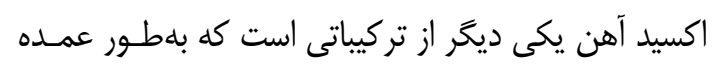

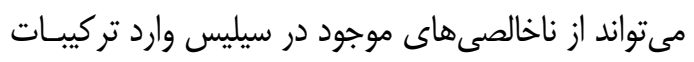
شيشه شود. بر اين اسـاس، يكـى ديخــــ از تركيبـاتى كـهـ

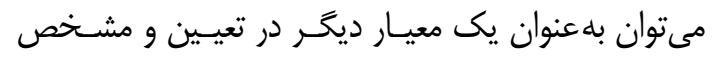

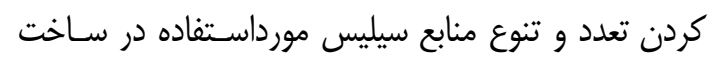

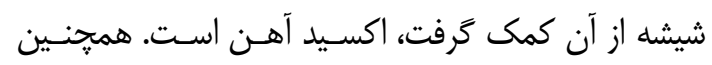

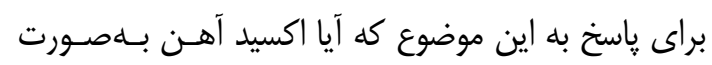

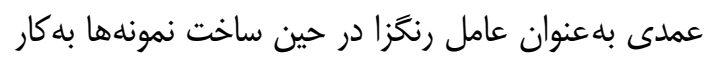

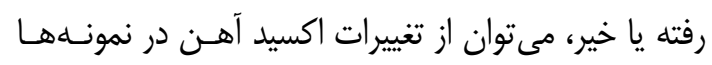

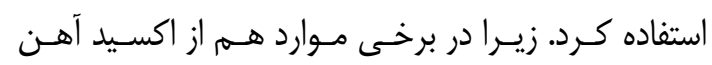

شيشه است، تغييرات گسترده آن مسىتوانــد نشـان دهنــده

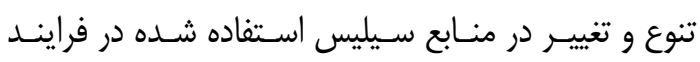
ساخت باشد[21]. بنابراين بر اساس تغييرات مقدار سيليس لتيس

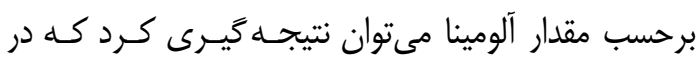
فرايند ساخت غالب شيشههاى مربوط به محوطه شائور از

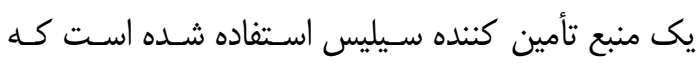

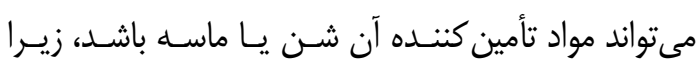
درصورتى كه منابع تأمين سيليس كانى هاى معدنى كـوارتز

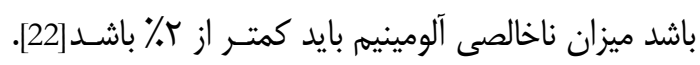

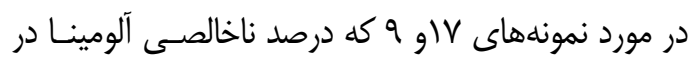

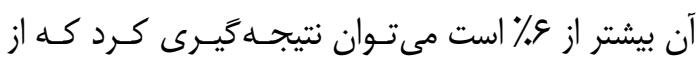

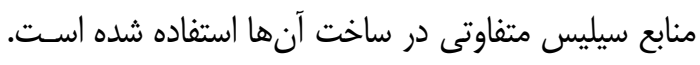

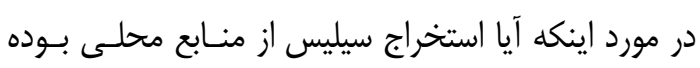

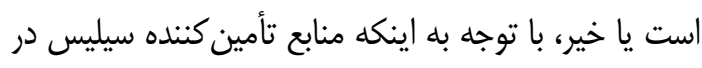

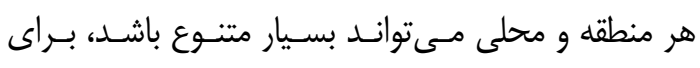
بررسى اين موضوع نيازمند نمونهبـردارى از منـابع متعـدد

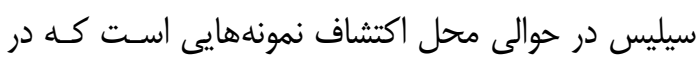

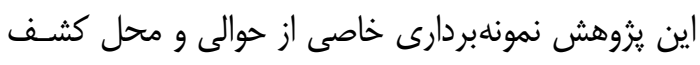

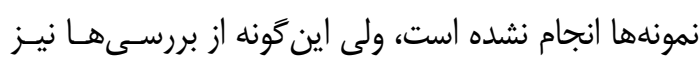

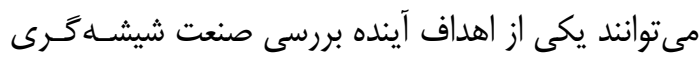

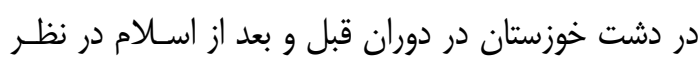

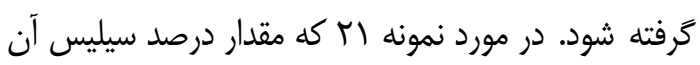




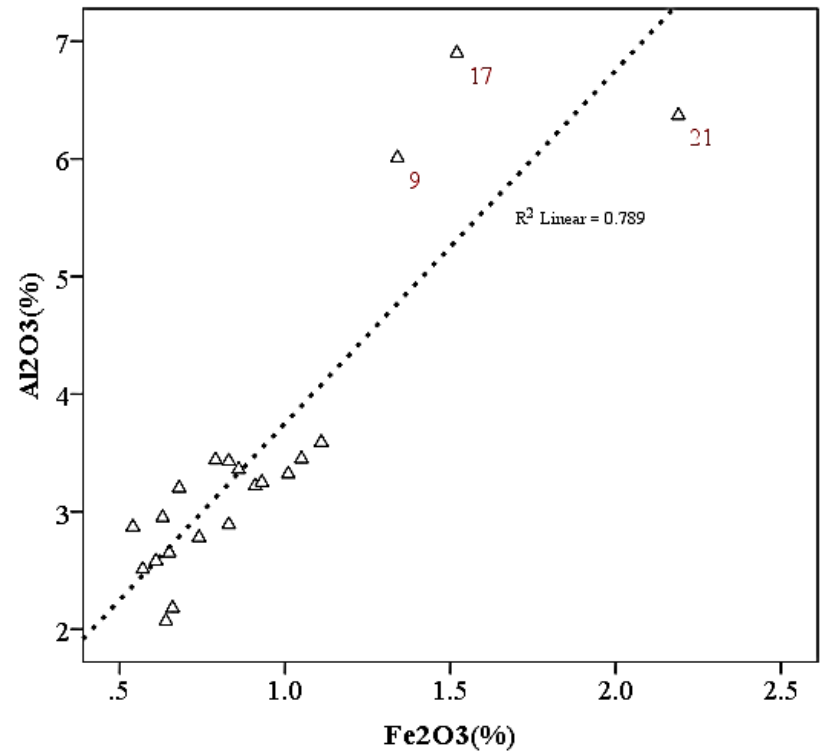

شكل أ تغييرات درصد وزنى اكسيد آهن برحسب اكسيد آلومينيم (آلومينا) در نمونههاى آناليز شده محوطه شائور

Fig. 4: Scatter plot of wt. \% of $\mathrm{Fe}_{2} \mathrm{O}_{3}$ versus $\mathrm{Al}_{2} \mathrm{O}_{3}$ in analyzed sample from shaur

اساس شكلهاى گ و أ به نظر مىرسد در فرايند سـاخت

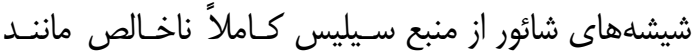

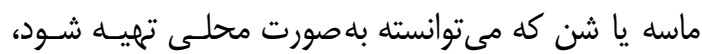
استفاده شده است.

\section{צ-r. بر برسى منابع تأمين سودا}

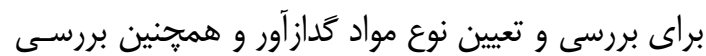

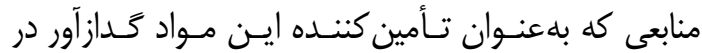

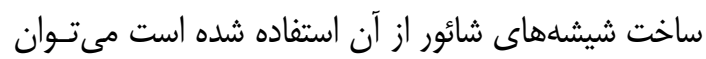

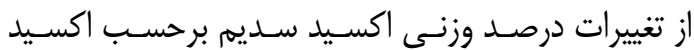

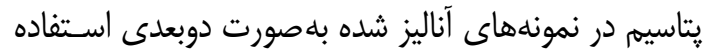

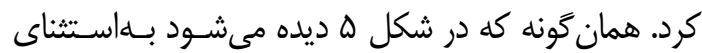

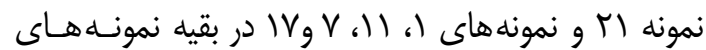

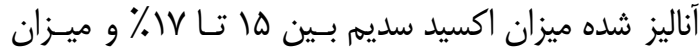

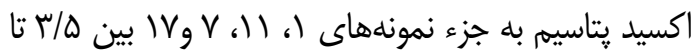
ه/ ه\% تغيير مى كند. بنابراين با توجه به مقادير اندازه كيرى شده، مشـخص اسـت كـه نــوع مـاده كَداز آورى كـه در شيشههاى بلهدستآمده در محوطـهـ شـائور اسـتفاده شـده است اكسيد سديم (سودا) است. همجنين با توجه به اينكه ميزان تغييـرات اكسـيد ســيم و اكسـيد پِتاسـيم در اكثـر

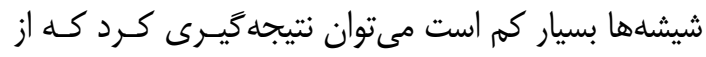

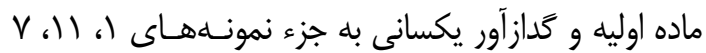

به عنوان عامل رنخزا و ايجاد طيـف رنخـى سـبز اسـتفاده

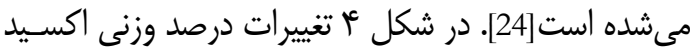

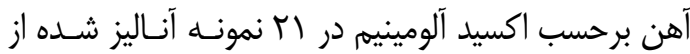
محوطه شائور نشان داده شده اسـت. همـان طـور كـهـ در

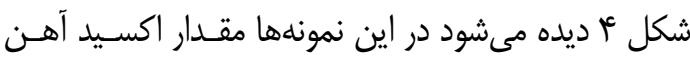

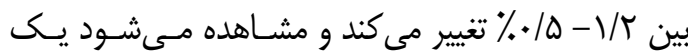
همبستخى خطى قوى بين اكسيد آلومينيم واكسيد آهن بـاــا

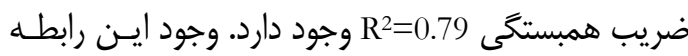
خطى اثبات مى كند كه اكسيد آهـن موجـود در نمونـهـهـا ناشى از ناخالصى موجود در سيليس استفاده شــــ اسـت و و كاملاً به صورت ناخواسته وارد نمونهها شده است. مطالعات

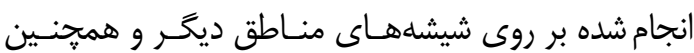
برخى از نمونههايى كه در دوران اسلامى در ايران سـاخته

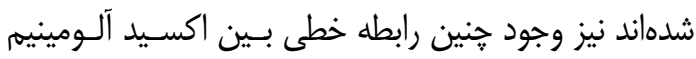
واكسيد آهن كه ناشى از ناخالصىهاى موجود در سـيليس مورداستفاده در فرايند ساخت است را كزارش مى كنـــ[6]. بر اساس شكل عأ مىتوان نتيجه كيرى كرد كـه در فراينــ

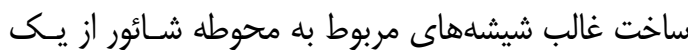
منبع تأمين كنتده سيليس استفاده شده است. همجنـين در

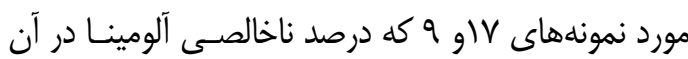

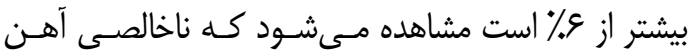
موجود در اين نمونهها نيز از إ) بيشتر است. بنـابراين بـر 


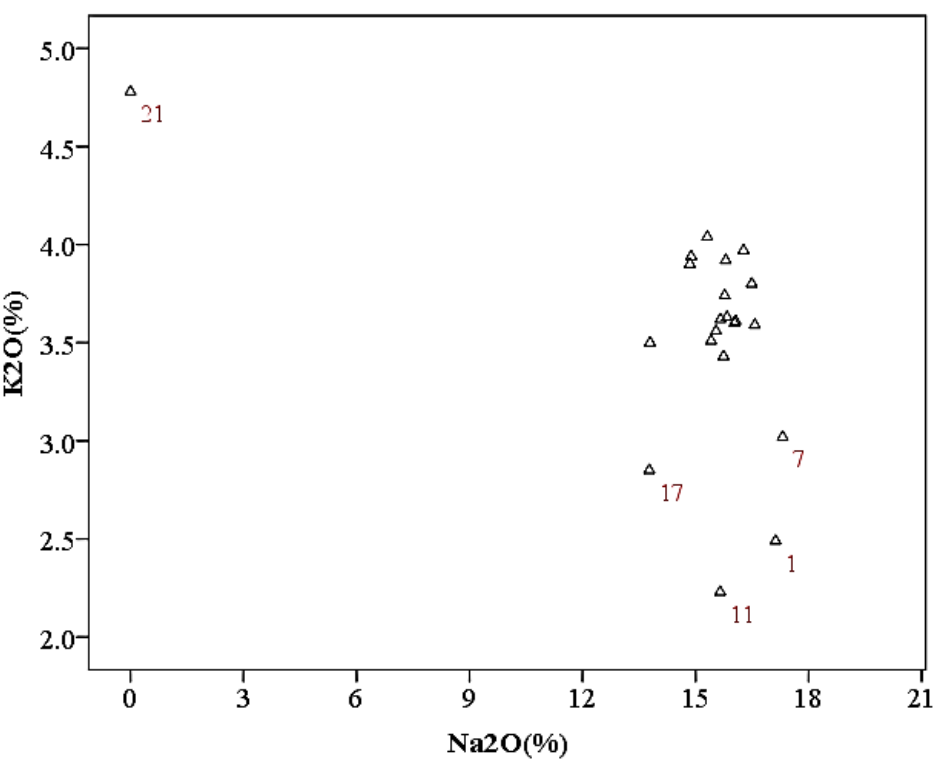

شكله: تغييرات درصد وزنى اكسيد سديم برحسب اكسيد پتاسيهم در نمونهاى آناليز شده از محوطه شائور

Fig. 5: Scatter plot of wt $\%$ of $\mathrm{Na}_{2} \mathrm{O}$ versus $\mathrm{K}_{2} \mathrm{O}$ in analyzed sample from shaur

مورداستفاده در ايـن نمونـههـا از منــابع معـدنى (نـاترون)

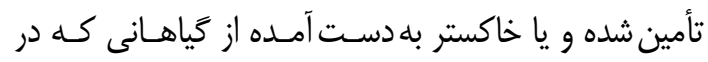

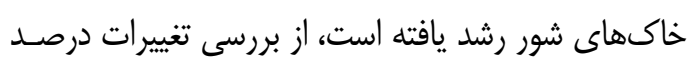

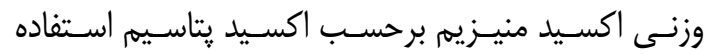

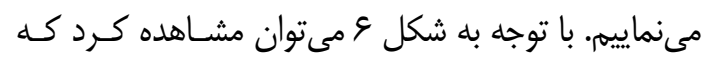

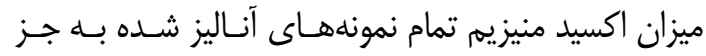

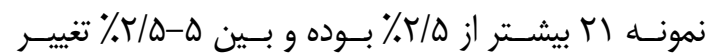

و ا در تأمين سوداى موردنياز در اين نمونـهـهـا استفاده

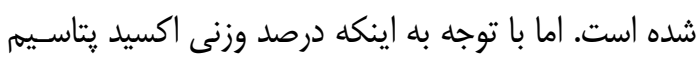

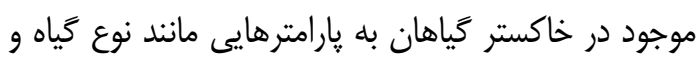

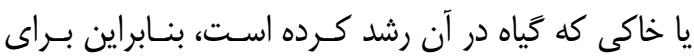

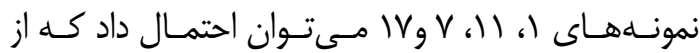
كياهان متفاوتى براى تهيه خاكستر استفاده شده است.

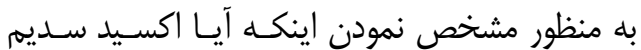

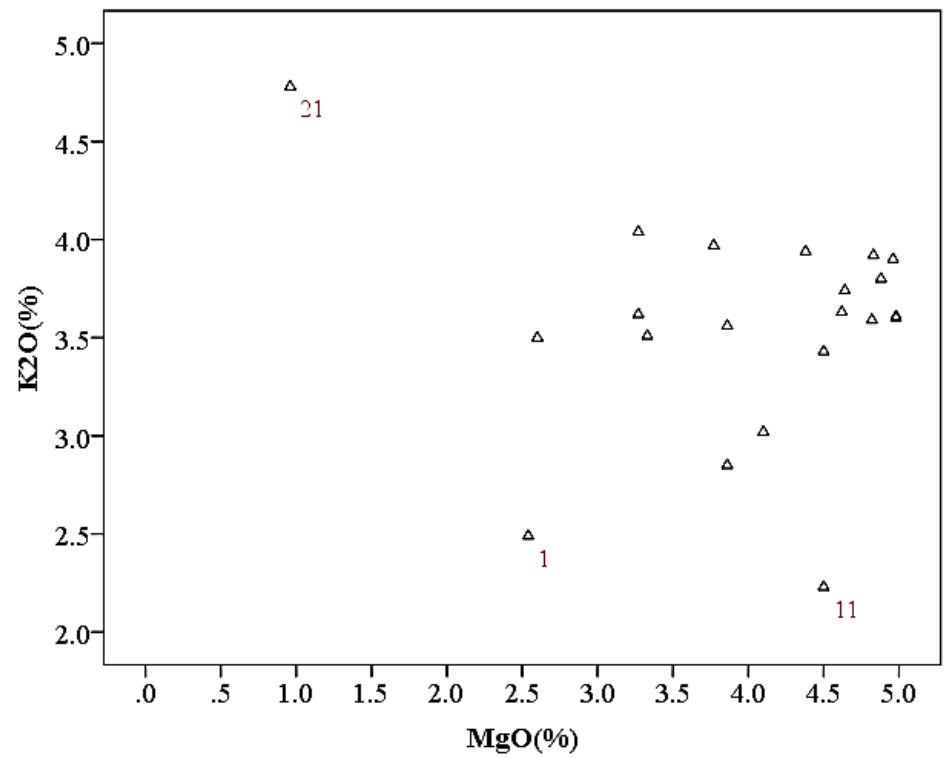

شكل : تغييرات درصد وزنى اكسيد منيزيم برحسب اكسيد يتاسيم در نمونههاى آناليز شده از محوطه شائور

Fig. 6: Scatter plot of wt\% of $\mathrm{MgO}$ versus $\mathrm{K}_{2} \mathrm{O}$ in analyzed sample from shaur 
و به نوع كَياه و همجنـين خـاكى كـه در آن رشــ كرده بستخى دارند[27]. در شكل V تغييرات درصد وزنى اكسـيد

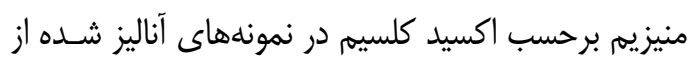
محوطه شائور نشان داده شده اسـت. نتـايج ايـن آناليزهـا

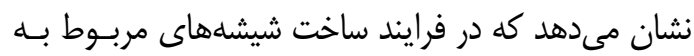

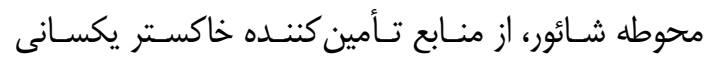

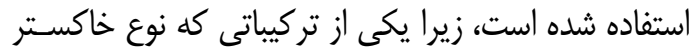

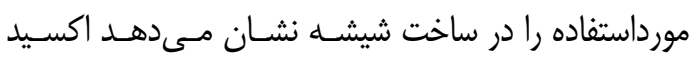

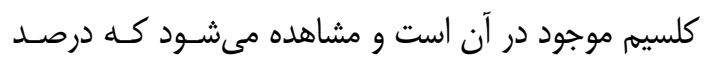

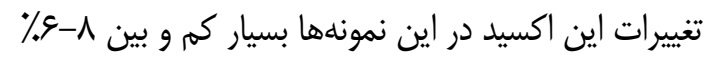

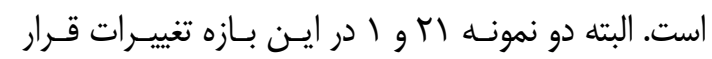

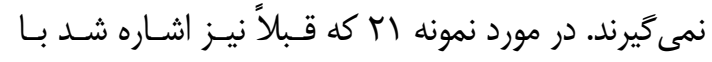

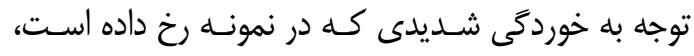

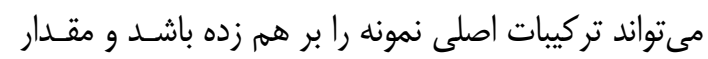

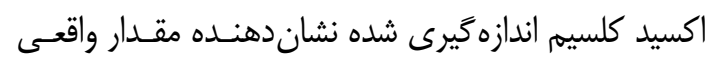

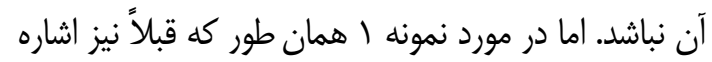

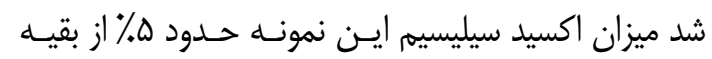

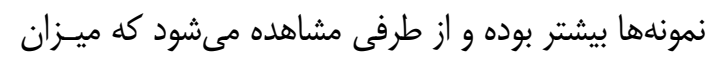

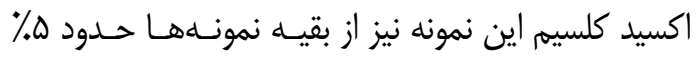

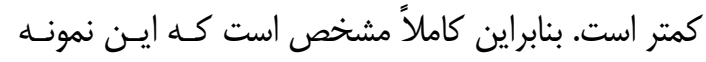

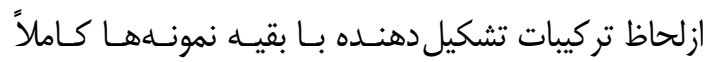

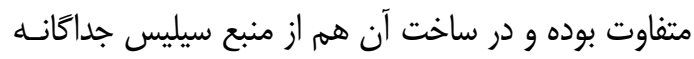

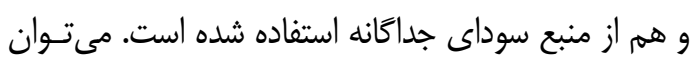

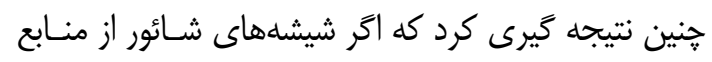
محلى و در محل توليد شده باشند، در بين اين شيشـهـهـا

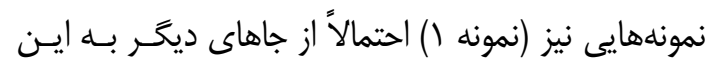

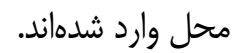

\section{צ-". بررسى مواد رنكَزا و رنَخَبر}

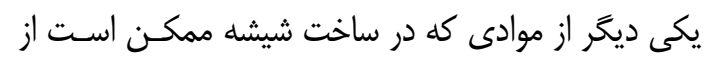

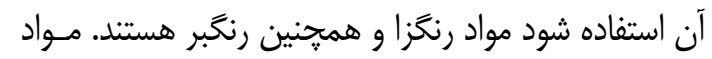

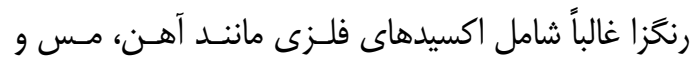

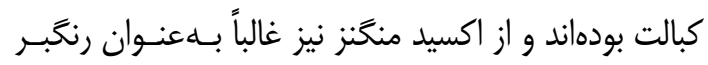

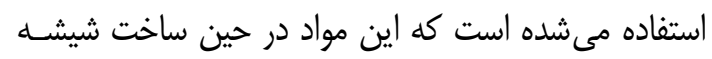

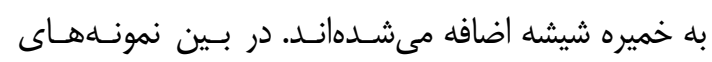

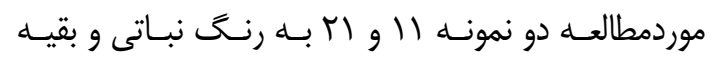
سبزرنح هستند. از طرفى بر اساس مراجع مختلـف يكى نهى

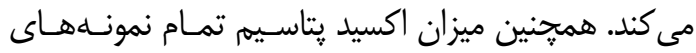

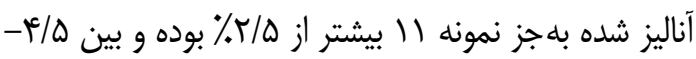

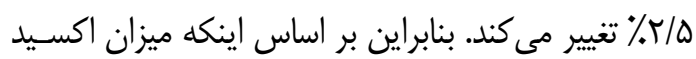

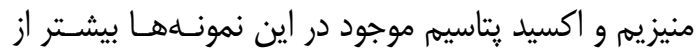

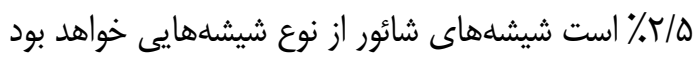

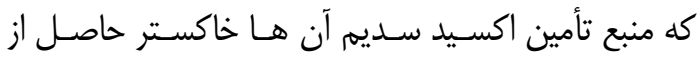
كَياهان رشد يافته در خاكهاى شور بوده است [20]. همان طور كه قبلاً نيز اشـاره كرديم تقريبـاً تـاكنون

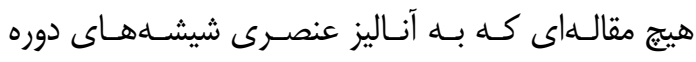

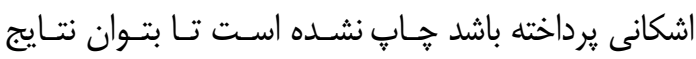

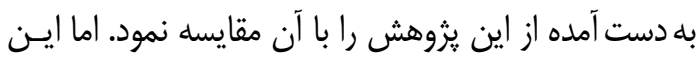

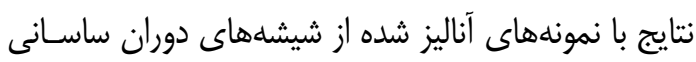

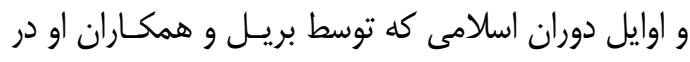

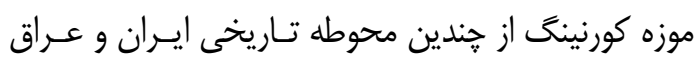

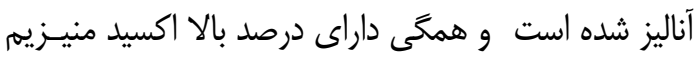

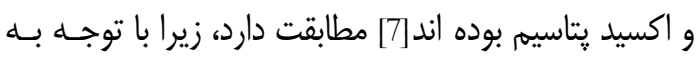

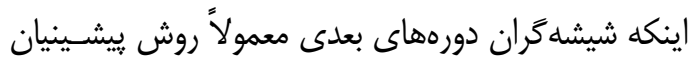

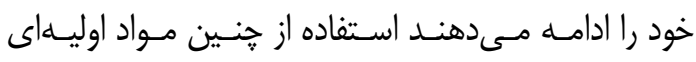

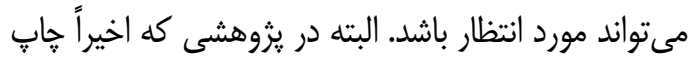
شده آناليز عنصرى تعداد محسـدودى از نمونـههــاى دوران

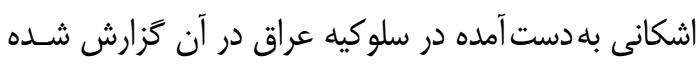

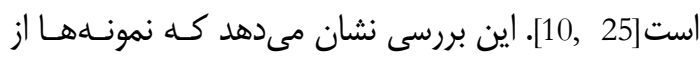
نوع شيشههاى ناترونى هستند و ازنظر مواد اوليه كاملاً بـا شيشههاى شائور اختاف دارند.

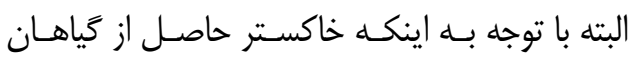

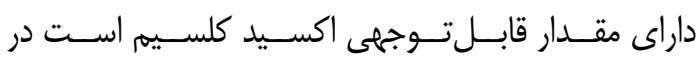

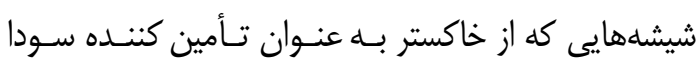

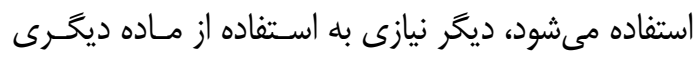

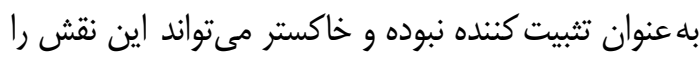

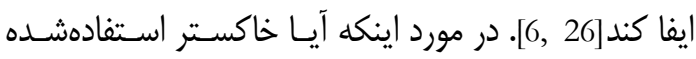

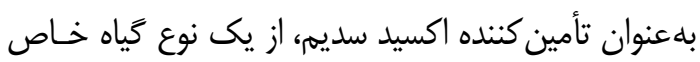

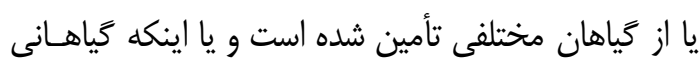

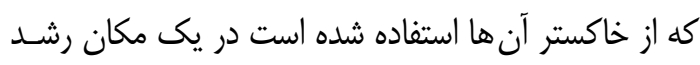

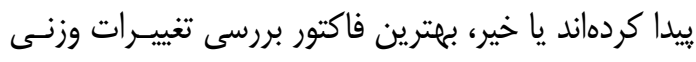

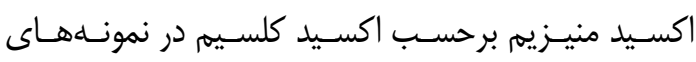

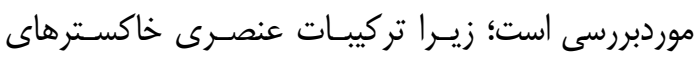

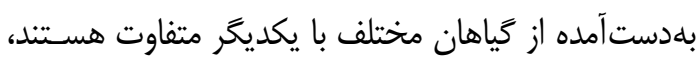




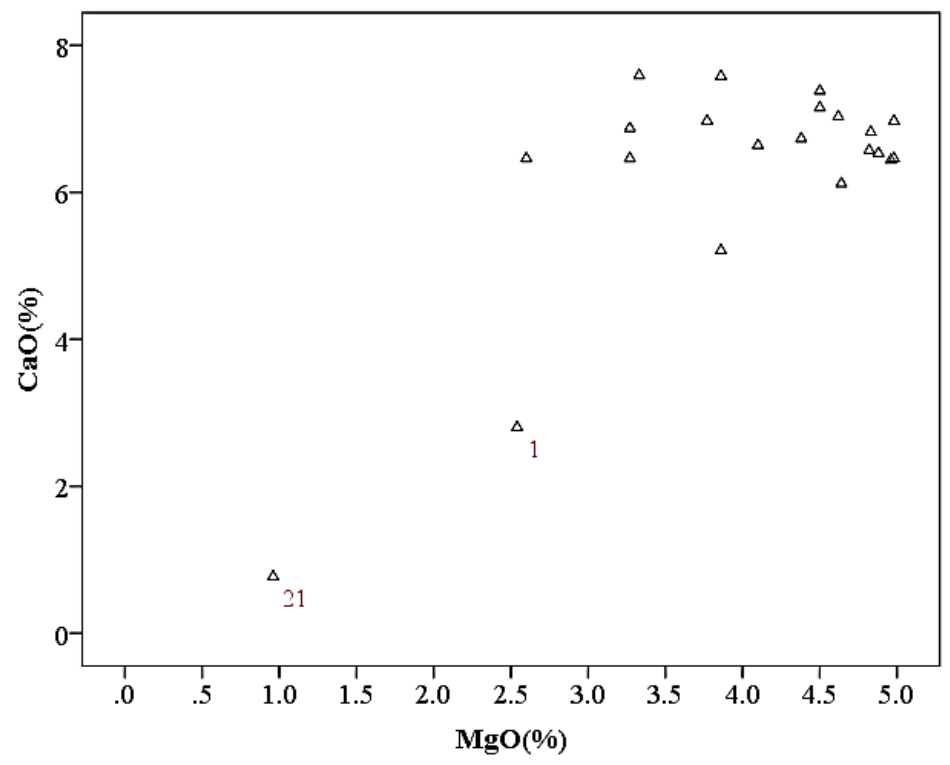

شكل V: تغييرات درصد وزنى اكسيد منيزيم برحسب اكسيد كلسيم در نمونهاى آناليز شده از محوطه شائور

Fig. 7: Scatter plot of wt. \% of $\mathrm{MgO}$ versus $\mathrm{CaO}$ in analyzed sample from shaur

شائور بلهورت دوبعدى رسم شـده اسـت. در ايسن شـكل

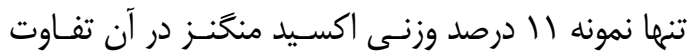

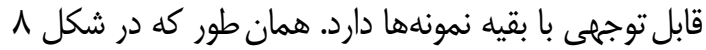

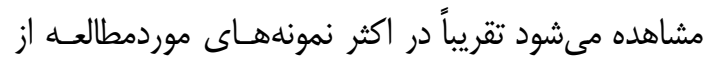

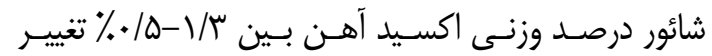
مى كند. همجنين مشاهده مىشود كه مقدار اكسيد منگَنـز

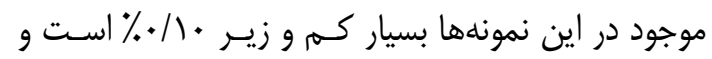

از تر كيباتى عامل ايجاد رنحَ سبز، اكسيد آهن اسـت[28].

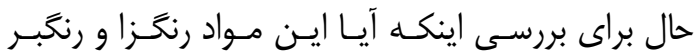

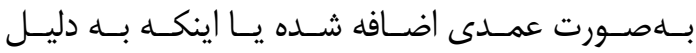
ناخالصىهاى موجود در سيليس بـوده اسـت، مسى بــوان از

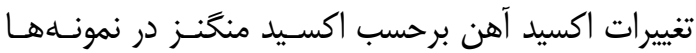
استفاده نمود. در شكل ^ متغييرات درصد وزنى اكسيد آهن برحسب اكسيد منكَنز در نمونههاى آناليز شده از محوطـهـ

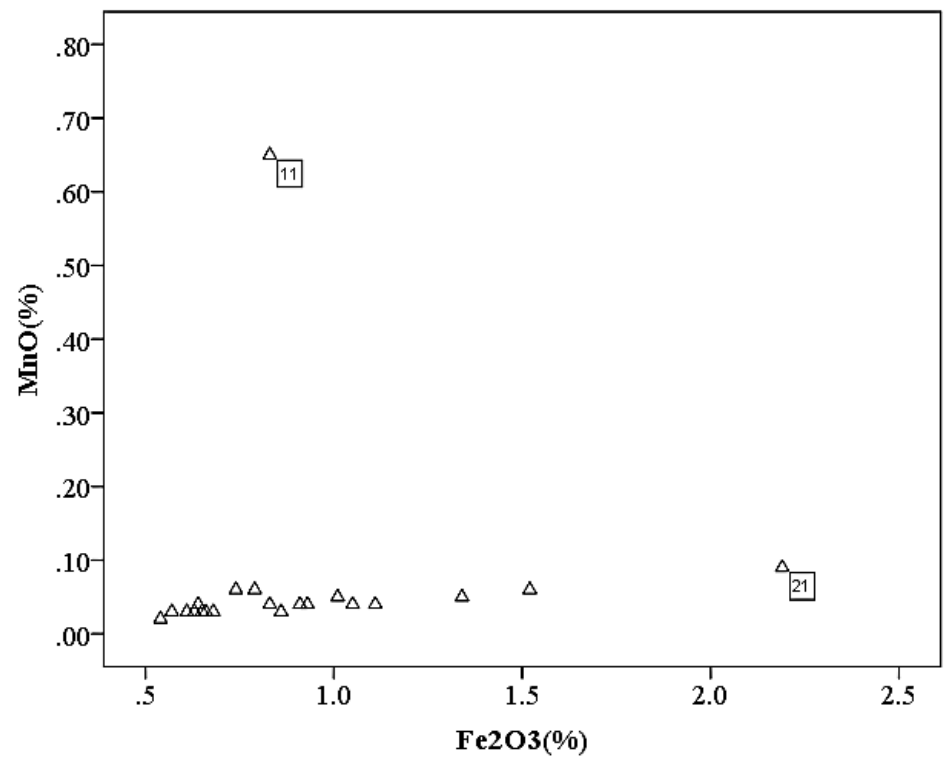

شكلم: تغييرات درصد وزنى اكسيد آهن برحسب اكسيد منگتنز در نمونهاى آناليز شده از محوطه شائور

Fig. 8: Scatter plot of wt. \% of $\mathrm{Fe}_{2} \mathrm{O}_{3}$ versus $\mathrm{MnO}$ in analyzed sample from shaur 
حاصل از خاكستر گياهـان هسـتند. ץ) ..مق.م تـا ..م ب.م در ارويا و آسياى غربى و ميانرودان از نـوع كَداز آَّر ناترون و در ايران و برخى كشورها همان سـوداى حاصل

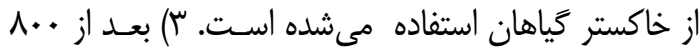

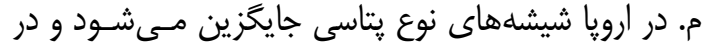
كشورهايى مانند عراق و سوريه و تركيه به سمت سـوداى ندائين

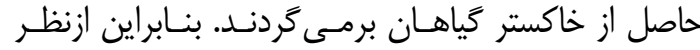

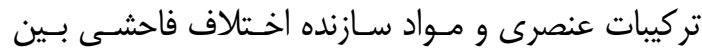
شيشههاى اشـكانى ايـران و كشـورهاى مجـاور هـمدوره

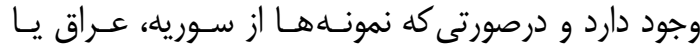
فلسطين واردشده باشند، اين اختـلاف در نــوع كَدازآ آورها غالباً خود را نشان مىدهد. از ديخر نتايج حاصل از آناليزها نمونهها اين است كه در فرايند ساخت شيشههاى مربـوط به محوطه شائور، از منابع تأمين كننده سـيليس و خاكسـتر

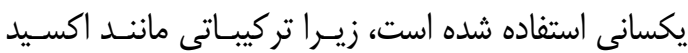

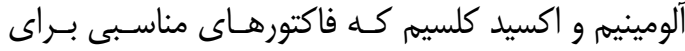
تعبيين منابع مورداستفاده به عنوان سيليس و سودا هسـتند، تقريباً در تمام نمونهها تغييرات نسبتاً كمى دارند. همجنين بر اساس برخى ديخر از ناخالصىهايى مانند اكسيد آهـن و

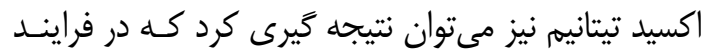

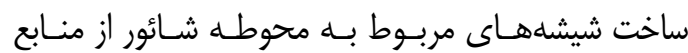
سيليكايى كاملاً يكسانى استفاده شده است كه اين منـابع

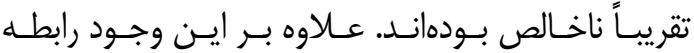
همبستخى بين اكسيد آهن و اكسيدهاى آلومينيم و تيتانيم

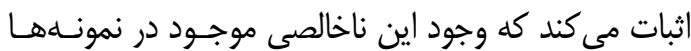

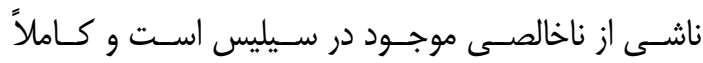

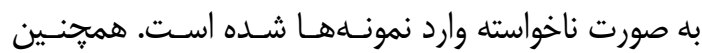
بررسى مقادير اكسيد آهن و اكسيد منگنز در اين شيشهها

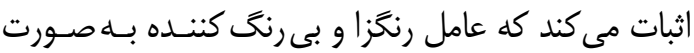
آكاهانه در طى فرايند ساخت به آنها اضافه نشده اسـت و

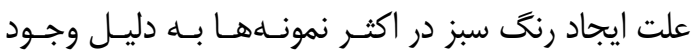
اكسيد آهن موجود در سيليس اسـت كهـ در حسين فراينـد حرارتدهى و ساخت طيف رنكى سبز به نمونه داده است.

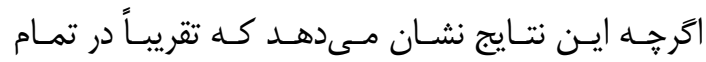

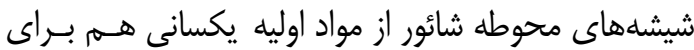
تهييه سيليس و هم براى تهيه سودا استفاده شده است امـا

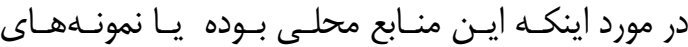
$s \mu$

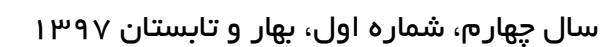

بين 9.|.- ץ.|•٪ تغيير مى كند. البته بين اكسيد آهن و

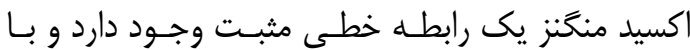

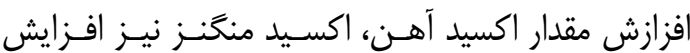
مىيابد. وجود اين رابطه خطى اثبات مى كند كـه اكسـيد

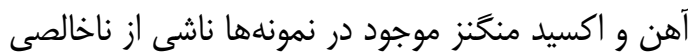

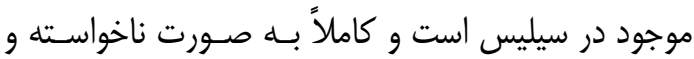

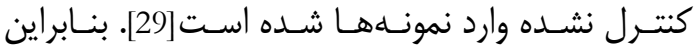

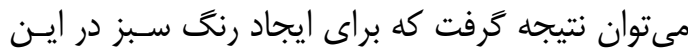

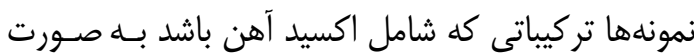
عمدى در حين فرايند ساخت اضافه نشده است. همجنين

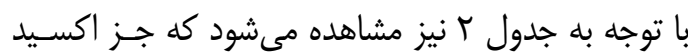
آهن، تركيبات رنخزاى عمدهاى در نمونهها مشاهده نشده است. همجنين لازم است كه اشاره شود كه اكسيد منكَنز

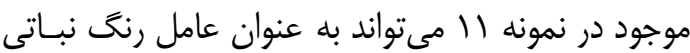

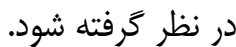

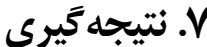

نتايج بهدستآمده از بررسـى نمونـهـهـاى محوطـهـ شـائور

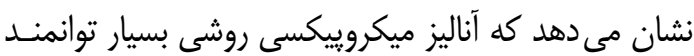

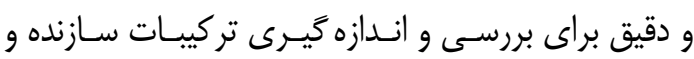

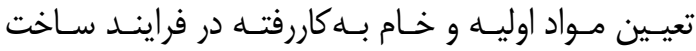
شيشههاى تاريخى هستند. حتى در مورد نمونههـايى كـه

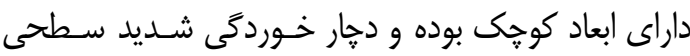
هستند، اين فن آناليز در مقايسه بـا فنـون آنـاليز مرسـوم

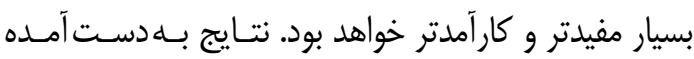
براى ميزان سيليس، اكسيد سديم و اكسيد كلسـيم نشـان مىدهد نوع تمام شيشههاى بلهدستآمده در محوطه شائور

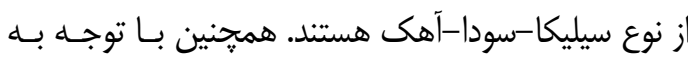
اينكه ميزان اكسـيد منيـزيم و اكسـيد پِتاسـيم موجـود در

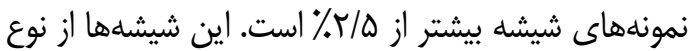

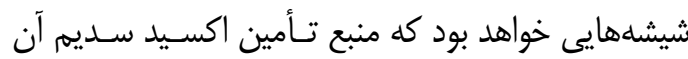
خاكستر حاصل از كَياهان رشد يافته در خـاكهـاى شـور

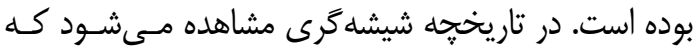

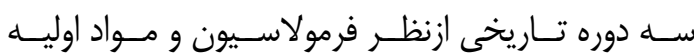
مورداستفاده براى شيشههاى سيليكا-آهك-سودا استفاده شده است: () از ابتداى يبدايش تا . •1 ق.م معمولاً تمـام

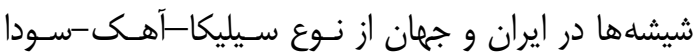




$$
\text { ازنظر مواد اوليه اختلاف دارند. }
$$

\section{سياسگز ارى}

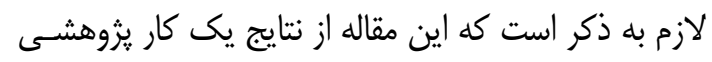

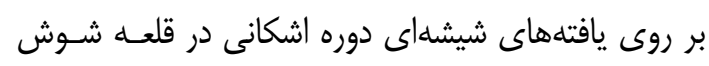

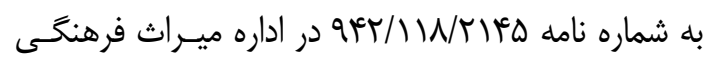

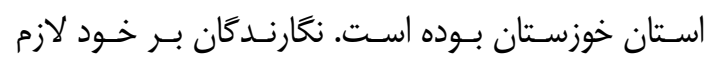

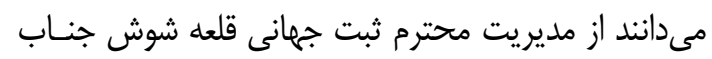

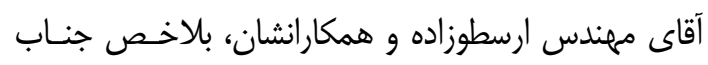

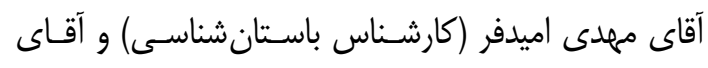

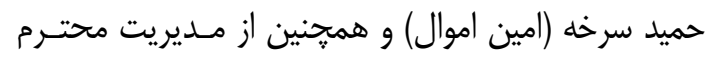

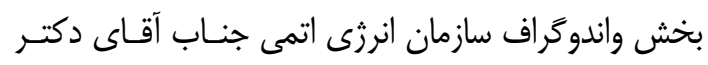

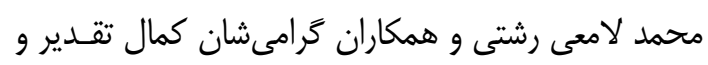
تشكر را به جا آورند.

\section{References}

[1] Moorey PRS. Ancient mesopotamian materials and industries: the archaeological evidence. Clarendon. Oxford; 1994.

[2] Celik S, Akyuz T, Akyuz S, Ozel A, KecelGunduz S, S B. Investigations of Archaeological Glass Bracelets and Perfume Bottles Excavated in Ancient Ainos (Enez) by Multiple Analytical Techniques. J Appl Spectrosc. 2018;(85):178-83.

[3] Oikonomou A, Henderson J, Gnade M, Chenery S, Zacharias N. An archaeometric study of Hellenistic glass vessels: evidence for multiple sources. Archaeol Anthropol Sci. Springer; 2018;10(1):97-110.

[4] Henderson J, Chenery S, Faber E, Kröger J. The use of electron probe microanalysis and laser ablation-inductively coupled plasma-mass spectrometry for the investigation of 8th-14th century plant ash glasses from the Middle East. Microchem J. Elsevier; 2016;128:134-52.

[5] Bugoi R, Alexandrescu C-G, Panaite A. Chemical composition characterization of ancient glass finds from Troesmis-Turcoaia, Romania. Archaeol Anthropol Sci. Springer; 2018;10(3):571-86.

[6] Henderson J. Ancient glass: an interdisciplinary exploration. Cambridge University Press; 2013.

[7] Brill RH, Stapleton CP. Chemical analyses of early glasses: volume 3: the years 2000-2011, reports, and essays. Corning Museum of Glass; 2012.

[8] Swan CM, Rehren T, Lankton J, Gratuze B, Brill RH. Compositional observations for Islamic Glass from Sīrāf, Iran, in the Corning

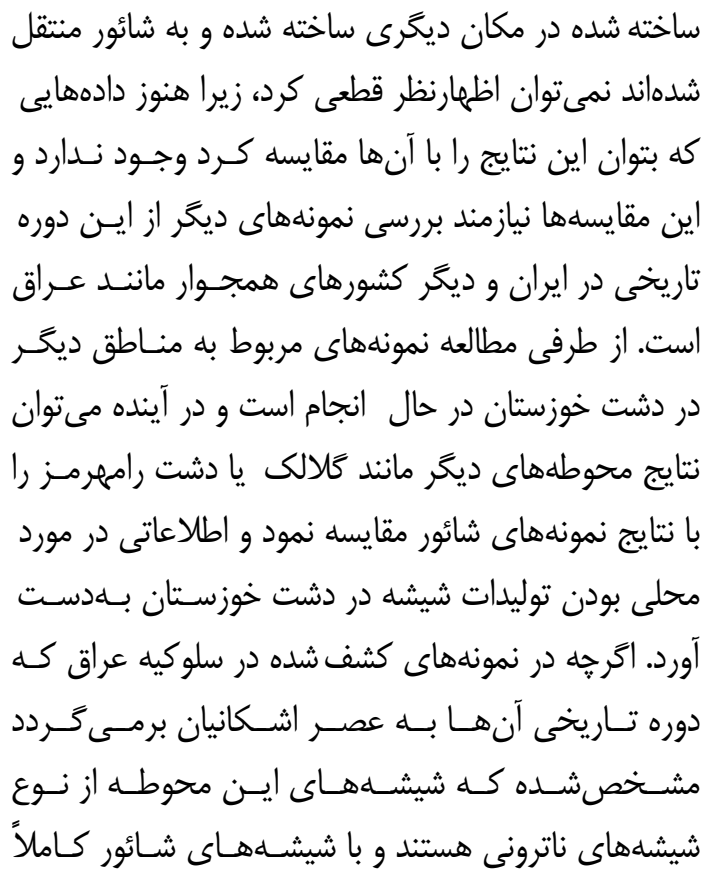

Museum of Glass collection. J Archaeol Sci Reports. Elsevier; 2017;16:102-16.

[9] De Schauensee M. Peoples and Crafts in Period IVB at Hasanlu, Iran. Vol. 132. University of Pennsylvania Press; 2012.

[10] Mirti P, Pace M, Negro Ponzi M, Aceto M. ICP-MS Analysis of Glass Fragments of Parthian And Sasanian Epoch from Seleucia and Veh Ardaš?R (Central Iraq). Archaeometry. Blackwell Publishing Ltd; 2008 Jun;50(3):429-50. Available from: http://dx. doi.org/10.1111/j.1475-4754.2007.00344.x

[11] Kordavani M. Achamenid Palace of Shaur, excavations at Susa during 1971-1972. Bita; 1977. [in Persian]

[كردوانى محمود. كاخ هخامنشى شـاهور. كـاوشهـاى

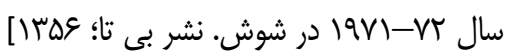

[12] Boucharlat R, Labrousse A. Le palais d'ArtaxerxèsII sur la rive droite du Chaour à Suse. Cah la Délégation Archéologique Française en Iran Paris. 1979;10:19-136.

[13] Sheikh M. Achamenid period at Susa ancient site according to archaeological excavations [Unpublished M.A thesis]. Islamic Azad University of Tehran; 2007. [in Persian]

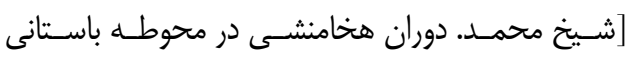
شوش بر اساس كاوشهاى باستانشناسى [منتشرنشده].

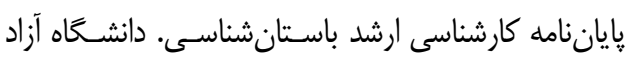

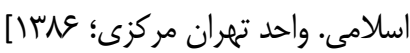

[14] Yoyotte J. Les inscriptions hiéroglyphiques de la statue de Darius à Suse. Délégation

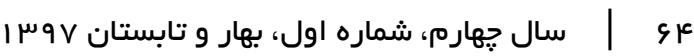


archéologique française en Iran; 1974.

[15] Johansson SAE, Campbell JL. PIXE: A novel technique for elemental analysis. 1988;

[16] Schmidt B, Wetzig K. Ion beams in materials processing and analysis. Springer Science \& Business Media; 2012.

[17] Adams F, Barbante C. Particle-Based Imaging Techniques. In: Comprehensive Analytical Chemistry. Elsevier; 2015. p. 315-37.

[18] Campbell JL, Boyd NI, Grassi N, Bonnick P, Maxwell JA. The Guelph PIXE software package IV. Nucl Instruments Methods Phys Res Sect B Beam Interact with Mater Atoms. Elsevier; 2010;268(20):3356-63.

[19] Agha-Aligol D, Oliaiy P, Mohsenian M, Lamehi-Rachti M, Shokouhi F. Provenance study of ancient Iranian luster pottery using PIXE multivariate statistical analysis. J Cult Herit. Elsevier; 2009;10(4):487-92.

[20] Sayre E V, Smith RW. Compositional categories of ancient glass. Science. American Association for the Advancement of Science; 1961;133(3467):1824-6.

[21] Lima A, Medici T, de Matos AP, Verità M. Chemical analysis of 17 th century Millefiori glasses excavated in the Monastery of Sta. Clara-a-Velha, Portugal: comparison with Venetian and façon-de-Venise production. J Archaeol Sci. Elsevier; 2012;39(5):1238-48.

[22] Freestone IC, Jackson-Tal RE, Taxel I, Tal O. Glass production at an early Islamic workshop in Tel Aviv. J Archaeol Sci. Elsevier; 2015;62:45-54.

[23] Weber G, Strivay D, Martinot L, Garnir H-P. Use of PIXE-PIGE under variable incident angle for ancient glass corrosion measurements. Nucl Instruments Methods
Phys Res Sect B Beam Interact with Mater Atoms. Elsevier; 2002;189(1-4):350-7.

[24] Van der linden V, Cosyns P, Schalm O, Cagno S, Nys K, Janssens K, et al. Deeply coloured and black glass in the Northern provinces of the Roman empire: Differences and similarities in chemical composition before and after AD 150. Archaeometry. Blackwell Publishing Ltd; 2009 Oct;51(5):822-44. Available from: http://dx.doi.org/10.1111/j.1475-4754.2008. 00434.x

[25] Ganio M, Gulmini M, Latruwe K, Vanhaecke F, Degryse P. Sasanian glass from Veh Ardašīr investigated by strontium and neodymium isotopic analysis. J Archaeol Sci. Elsevier; 2013;40(12):4264-70.

[26] Kato N, Nakai I, Shindo Y. Change in chemical composition of early Islamic glass excavated in Raya, Sinai Peninsula, Egypt: onsite analyses using a portable $\mathrm{X}$-ray fluorescence spectrometer. J Archaeol Sci. Elsevier; 2009;36(8):1698-707.

[27] Freestone IC, Jackson-Tal RE, Tal O. Raw glass and the production of glass vessels at late Byzantine Apollonia-Arsuf, Israel. J Glass Stud. JSTOR; 2008;67-80.

[28] Vataj E, Hobdari E, Röhrs S, Vandenabele P, Civici N. Analytical characterization of glass tesserae from mosaics of early Christian basilicas in Albania. Appl Phys A. Springer; 2017;123(1):76.

[29] Alberta S, Gianmario M, Valentina P. The stained glass window of the southern transept of St. Anthony's Basilica (Padova, Italy): study of glasses and grisaille paint layers. Spectrochim Acta Part B At Spectrosc. Elsevier; 2011;66(1):81-7. 